\title{
Role of Transcriptional Regulation in the Evolution of Plant Phenotype: A Dynamic Systems Approach
}

\author{
Emiliano Rodríguez-Mega, ${ }^{1}$ Alma Piñeyro-Nelson, ${ }^{2}$ Crisanto Gutierrez, ${ }^{3}$ Berenice García-Ponce, ${ }^{1}$ María De La Paz Sánchez, ${ }^{1}$ \\ Estephania Zluhan-Martínez, ${ }^{1}$ Elena R. Álvarez-Buylla, ${ }^{1}$ and Adriana Garay-Arroyo ${ }^{1,3 *}$ \\ ${ }^{1}$ Laboratorio de Genética Molecular, Desarrollo, Evolución y Epigenética de Plantas, Universidad Nacional Autónoma de México, $3^{\text {er }}$ Circuito Exterior junto al Jardín \\ Botánico, Ciudad Universitaria, México \\ ${ }^{2}$ Department of Plant and Microbial Biology, University of California, Berkeley, California \\ ${ }^{3}$ Centro de Biología Molecular Severo Ochoa, CSIC-UAM, Nicolás Cabrera 1, Cantoblanco, 28049 Madrid, Spain
}

A growing body of evidence suggests that alterations in transcriptional regulation of genes involved in modulating development are an important part of phenotypic evolution, and this can be documented among species and within populations. While the effects of differential transcriptional regulation in organismal development have been preferentially studied in animal systems, this phenomenon has also been addressed in plants. In this review, we summarize evidence for cis-regulatory mutations, trans-regulatory changes and epigenetic modifications as molecular events underlying important phenotypic alterations, and thus shaping the evolution of plant development. We postulate that a mechanistic understanding of why such molecular alterations have a key role in development, morphology and evolution will have to rely on dynamic models of complex regulatory networks that consider the concerted action of genetic and nongenetic components, and that also incorporate the restrictions underlying the genotype to phenotype mapping process. Developmental Dynamics 244:1074-1095, 2015. ๑ 2015 Wiley Periodicals, Inc.

Key words: phenotypic evolution; gene regulation; epigenetics; evo-devo; gene regulatory networks

Submitted 16 October 2014; First Decision 24 February 2015; Accepted 24 February 2015; Published online 2 March 2015

\section{Introduction}

In this review article, we will provide evidence to connect natural phenotypic variation in plants to heritable changes in epigenetic and transcriptional regulation and discuss how plant phenotypic alteration can be explained by the relative position of regulators within gene regulatory networks. In the first section of the article, we show how plant phenotypic variation can be generated by different mechanisms of gene transcriptional regulation. The second section comprises diverse evidence for plant phenotypic evolution related to three main regulatory alterations: epigenetic modifications, cis-regulatory changes, and trans-regulatory changes. We also briefly talk about the fitness costs of natural regulatory variation in plant populations. Finally, we address the importance of a systems perspective for understanding how genetic and epigenetic alterations map onto phenotypic changes by altering complex gene regulatory networks and affecting the evolution of

Grant sponsor: CONACyT; Grant number: 180098; Grant number: 180380; Grant number: 167705; Grant number: 152649; Grant sponsor: PAPIIT UNAM; Grant number: IN203214-3; Grant number: IN203113-3; Grant number: IN203814-3; Grant sponsor: MINECO; Grant number: BFU2012-34821.

"Correspondence to: Adriana Garay-Arroyo, Laboratorio de Genética Molecular, Desarrollo, Evolución y Epigenética de Plantas, Universidad Nacional Autónoma, de México, 3er Circuito Exterior junto al Jardín Botánico, Ciudad Universitaria, México, D.F. 04510, Mexico.

E-mail: garay.adriana@gmail.com plant phenotype, and discuss some of the technological approaches that could advance this field.

\section{Background}

In the early 20th century, the modern evolutionary synthesis came to reconcile the mechanisms of inheritance studied through Mendelian genetics with inquiries on the role of natural selection and gradual transition in an attempt to explain the evolution and diversification of life forms. The synthesis generated a strong conceptual framework but failed to satisfactorily address one of the oldest biological problems: how phenotypic variation is generated and modulated within and among species (Stern, 2000; Müller, 2007; Carroll, 2008; Gilbert and Epel, 2009; Willmore, 2012).

In the modern synthesis, the findings and conceptual contributions of several disciplines such as embryology, paleontology, physiology, and developmental biology in general were left aside. These disciplines continued pursuing their research lines, many addressing evolutionary problems, but outside of the realm of the conceptual framework set forth by the modern synthesis (Love and Raff, 2003; Willmore, 2012). The discovery of DNA as the material basis of inheritance and the availability of different

Article is online at: http://onlinelibrary.wiley.com/doi/10.1002/dvdy. 24268/abstract

(C) 2015 Wiley Periodicals, Inc. 
techniques to manipulate and test the phenotypic response to genetic manipulation marked the start of developmental genetics, first deployed in animal research (Love and Raff, 2003; Müller, 2007). Developmental genetics tried to build mechanistic explanations based on molecular phenomena for the morphological and physiological observations, in an effort to bridge the gap between genotype and phenotype. Evolutionary developmental biology (also called evo-devo) was thus born in the beginning of the 1990s as a collective effort to assign development its proper place within the modern evolutionary theory.

\section{From Genes to Phenotype and Back: The Long and Winding Road}

As a result of its recent creation, the core and shared tenets of evo-devo, and the practices that are considered part of its conceptual framework, have remained in flux. Nevertheless, it is of general consensus that one of its central objectives is the understanding of not just which genetic alterations during development influence organismal phenotypic change but how they do so (Raff, 2000; Wilkins, 2002; West-Eberhard, 2003; Carroll, 2008; Stern, 2010; Wray, 2013). In this regard, one of its most important and widely accepted contributions to evolutionary theory is the idea that alterations in gene regulation represent the most significant causal basis of phenotypic change and evolution, at least in animals (Hoekstra and Coyne, 2007).

A significant amount of research effort in evo-devo has focused on studying the regulatory logic of developmental networks that underlie evolutionary novelties (Müller, 2007). While it is true that "development is larger than just developmental genetics", because it is now well known that the phenotype of an organism arises from the interaction between its genotype, the environment, and other nongenetic aspects, such as physical forces or chemical fields (Gilbert et al., 2010), gene regulation and intracellular networks of gene interactions are key for cellular differentiation, pattern formation, and morphogenesis that give rise to the phenotypic characteristics of multicellular organisms (Carroll, 2008; Wray et al., 2003; Wray, 2007; Wittkopp and Kalay, 2012).

This view is not novel at all. Several cornerstone manuscripts published from the 1960s onward provided strong theoretical support for the observations that changes in regulatory sequences should be considered as an important element in the genetic component of the evolutionary process (Jacob and Monod, 1961; Wallace, 1963; Britten and Davidson, 1969, 1971; King and Wilson, 1975; Jacob, 1977). Since then, molecular changes in regulatory sequences that can modify gene expression patterns started to be seen as more likely events involved in creating phenotypic variation than coding mutations (Carroll, 2005, 2008). This was based in two main observations: (1) proteins from different species exhibited neutral mutations over time without any apparent effect on function and (2) proteins involved in gene regulation, such as transcription factors, exhibited a high structural and functional conservation between distantly related species (Zuckerkandl, 1968; King and Wilson, 1975). Today, a growing body of evidence suggests that alterations in spatial and temporal patterns of gene expression can be associated with phenotypic changes.

Nevertheless, phenotype not only evolves by means of regulatory changes in the spatio-temporal regulation of transcription, but also due to changes in the mRNA, the miRNA or protein sequences, and both types of alterations have demonstrated to contribute differentially to the generation of new phenotypes (Wittkopp et al., 2004; Rieseberg and Blackman, 2010; Gruber et al., 2012; Meiklejohn et al., 2014).

Studying multicellular organisms poses a conundrum: if all the constituent cells share the same genome, why do they only synthesize the genetic products related to the tissue type they belong to? A partial answer to this issue is provided by the observation that diverse cell lineages have differential gene expression profiles: each cell type expresses only a certain percentage of its genome in a specific space and time and such expression is inherited by subsequent generations of cells from a particular tissue, delimiting different body parts and changing in response to environmental stimuli (Latchman, 2008). But the latter observation does not provide a mechanism, only a description and correlation of patterns.

More recently, a view that integrates different components and levels of regulation into formal and computational models of complex networks is emerging. Such approach aims at understanding the mechanistic basis of development and evolutionary change, by further comprehending how the genotype maps to, and responds to feedback from the phenotype, and the environment (West-Eberhard, 2003; Álvarez-Buylla et al., 2007; Benítez et al., 2013). Previous theoretical studies had already proposed that the emergent stable configurations of multi-stable complex regulatory networks underlie the process of cell differentiation (Kauffman, 1969), thus solving the apparent paradox of multicellularity. But this model was dismissed because it was based on randomly generated theoretical networks; it was not until 1998 that the first regulatory network grounded on experimental data was proposed (Mendoza and Álvarez-Buylla, 1998).

This area of inquiry has exploded since then, providing a repertoire of regulatory modules that map into different, also modular, aspects of the phenotype (see for example Álvarez-Buylla et al., 2010a). Within such modules, some transcription factors have key positions, so that alterations in their expression levels or patterns of expression, or in those of their downstream genes, cause the multi-gene configurations or phenotypic state that emerges as a result of such complex regulatory networks to switch into another state. Undertaking mechanistic Gene Regulatory Network (GRN) approaches, can help contribute to the understanding of systemic properties of development such as robustness and evolvability of particular genetic modules involved in morphogenesis, and the role that epigenetic phenomena can have in explaining the developmental plasticity observed in studies documenting natural variation of a particular trait.

A complete algorithm for the complex series of events that occur during development to fully understand how the genotype maps unto the phenotype lies still ahead. As a complementary integrative task to understand such mapping, nonetheless, we review here the cases in which transcriptional regulatory alterations due to different altered regulatory mechanisms have been associated with important phenotypic changes in plants.

This article aspires to set the stage to establish multiple hypotheses concerning how the position of the suggested factors within regulatory modules may explain why their alterations are related to a modified phenotype. It is important for us to make clear that the approach we propose, then, does not suggest a oneto-one mapping from the genetic to the phenotypic alteration focusing on candidate genes, but rather a network-based analysis 
in which the position of the altered component with respect to other components in the network explains the emergence of a novel trait. This approach will also help mechanistically and formally frame most of the ongoing discussions concerning the relative importance of different types of molecular alterations during the evolution of plant phenotype.

\section{Complexity of Regulatory Pathways in Plants}

Presumably, the different regulatory processes affecting gene activity in eukaryotic cells allowed for an increase in genomic complexity (Beckerman, 2005). This is particularly true for organisms like plants. Plant genomes may have one of the most sophisticated genetic regulatory logics of all, a likely consequence of plants being sessile, nonmotile organisms whose development plastically responds to environmental conditions. Genome-wide comparative analyses suggest that transcriptional regulation may play a larger role in plants than in animals, because plants use a higher percentage of their genome to codify transcriptional regulators than animals or fungi (Riechmann et al., 2000; Gong et al., 2004; Xiong et al., 2005). An example that illustrates the contrasting strategies deployed by plants and animals to fine-tune gene expression and protein turnover is the case of the MADS-box family evolution in plants. Studies addressing the role of genomic duplications in plant evolution have highlighted that several whole genome duplications predate the diversification of plant lineages such as the angiosperms (Soltis et al., 2009). Whole genome duplications are now recognized as common phenomena that could have impelled lineage diversification through the inauguration of novel molecular interactions among homolog genes; differential selection of some duplicates involved in novel traits and, importantly, modifications of the underlying GRNs. Additionally, gene duplication events are also common, particularly in genes that control developmental processes throughout the plant's life cycle, as is the case for the MADS-box genes (Martínez-Castilla and Álvarez-Buylla, 2003). The MADS-box gene family comprises transcription factors that have a canonical DNA-binding domain of approximately 58 amino acids that binds to target DNA in consensus sequences called CArG boxes (Álvarez-Buylla et al., 2000; Parenicová et al., 2003). While MADS-box genes already existed in the common ancestor of animals and plants (Álvarez-Buylla et al., 2000), they have greatly diversified and expanded in plants, with over 100 type II MADS-box genes documented for A. thaliana (Martínez-Castilla and Álvarez-Buylla, 2003). Work in additional angiosperm species has shown that this is a general trend where the gene products of duplication events can either become redundant, be lost, subfunctionalize, or neofunctionalize (Airoldi and Davies, 2012); these molecular processes commonly have a direct impact on plant morphogenesis.

In the absence of any kind of migratory behavior, nervous system, or the gene rearrangements associated with animal acquired immunity, plants display a range of phenotypes when faced with external biotic or abiotic agents and continuously adjust their development and morphology to cope with surrounding conditions (Schlichting, 1986). This is known as phenotypic plasticity (West-Eberhard, 2003; Fordyce, 2006), and it is believed to drive, or at least facilitate, evolutionary change through its ecological effects (Price et al., 2003; Fordyce, 2006; Pigliucci et al., 2006; Ghalambor et al., 2007; Whitman and Agrawal, 2009).
How to link phenotypic plasticity with its underlying molecular mechanisms is a question that had been addressed since the early, 1990s by Smith (1990), Schlichting and Pigliucci (1993, 1995), who proposed that differential control of gene expression represented a "simple means for generating altered, yet still functional, phenotypes”. Years before, Schlichting (1986) had suggested that specific plastic responses in plants were determined by changes in the genetic bases controlling development.

Indeed, developmental plasticity is mainly the result of paramount pluripotent activity in stem cell populations that will either differentiate into organ types or produce more stem cells within plant meristems (Kaufmann et al., 2010). Two main meristems are observed in plants: the root apical meristem (RAM) localized in the root tip, that generates all underground structures, and the Shoot Apical Meristem (SAM), able to produce stems and leaves, and also inflorescences and flowers when it switches from a vegetative meristem to a reproductive one. Given that plants show an important postembryonic growth phase throughout their lifetime, these kind of developmental switches govern most organismal traits through changes in complex GRNs, where key transcriptional regulators orchestrate the expression of target genes involved in specific physiological processes, developmental pathways, and cell type identities (Lemon and Tjian, 2000; Kaufmann et al., 2010). Alterations in the interactions of a GRN can cause a switch from one stable state to another one, and thus underlie a plastic or permanent phenotypic alteration (Espinosa-Soto et al., 2004; Davidson and Erwin, 2006; Álvarez-Buylla et al., 2007; Peter and Davidson, 2011; Benítez et al., 2013).

Much emphasis has been placed on studying changes in transcriptional regulation that account for shifts in gene expression patterns and, ultimately, phenotypic variation (Carroll, 2005, 2008; Stern and Orgogozo, 2008; Wagner and Lynch, 2008). We would like to stress, nonetheless, that gene expression is altered at many other levels such that changes in additional regulatory mechanisms-alternative splicing, posttranscriptional regulation and translational regulation (Cohen and Mayfield, 1997; Alonso and Wilkins, 2005; Simpson et al., 2010)-require a specific review. In the forthcoming sections, we will encompass empirical evidence documenting different instances where altered transcriptional regulation underlies phenotypic evolution.

\section{Different Levels of Gene Transcriptional Regulation in Plants}

Another important conceptual contribution from the early proponents of evo-devo research is the notion that genetic networks likely underlying different developmental processes display a modular organization (Brakefield, 2006). Such modularity occurs at two different levels: (1) genes encompassed in a particular genetic module involved in the development of a given structure/ organ/trait can evolve in a semi-independent manner from other modules; and (2) each gene has a modular structure (comprised of cis-regulatory sequences, exons, introns) that, in itself, could be modified in a modular manner such that mutations occurring in the noncoding or coding sections can be independent from one another (Brakefield, 2006).

From a broad genetic perspective, two basic units of transcriptional regulation can be identified: trans-acting factors and cisacting elements (both trans- and cis- are latin prefixes which 
mean "on the other side of" and "on this side of", respectively; see Fig. 1). These units coordinate the spatiotemporal regulation of genetic expression, and work in a rather cooperative manner. Trans-acting factors include diffusible genetic products like regulatory proteins (i.e., transcription factors, hormones) and noncoding regulatory RNAs acting on distant target genes through the recognition of small allele-specific nondiffusible DNA sequences called cis-acting elements which are, in turn, embedded in noncoding cis-regulatory regions: promoters, enhancers, silencers, UTRs, as well as in intronic sequences (Stern and Orgogozo, 2008; Wagner and Lynch, 2008; Emerson and Li, 2010), although in rare cases they have also been discovered in exons (Neznanov et al., 1997; Sandrelli et al., 2001; see Fig. 1). According to their physical position relative to the gene they regulate, they can be divided into local and distant elements (Emerson and Li, 2010). These cis-acting elements, which work as binding sites, maintain transcriptional activity in a defined expression domain and are either involved in the basic process of transcription or in mediating the response to a particular stimulus (Wray et al., 2003; Latchman, 2008).

Experimental studies have shown that sequence changes in binding sites affect the affinity of transcription factor binding to DNA (Gompel et al., 2005; Jeong et al., 2006; Borneman et al., 2007; Odom et al., 2007; Tuch et al., 2008; Williams et al., 2008; Wilson et al., 2008; Schmidt et al., 2010; Zheng et al., 2010; Bradley et al., 2010; Kasowski et al., 2010). This is not trivial, because regulatory regions integrate information about the cell's developing state depending on which transcription factors bind to them (Latchman, 2008). A eukaryotic genome, for example, could have as many as $5 \times 10^{4}$ genes that need to be differentially expressed to develop into a specific cell type during ontogeny and to respond to several environmental stimuli during its lifespan (e.g., White et al., 1999; Iyer et al., 2001; Kayo et al., 2001; Mody et al., 2001; Arbeitman et al., 2002).

Successful expression of a given gene is controlled by the interplay among trans-acting factors, which recognize and bind specific cis-acting modules in regulatory regions, and subsequently recruit other protein intermediates to form molecular loops that bring together all the elements of the transcriptional machinery necessary to activate gene expression. These protein interactions are complex, nonlinear and often strongly context dependent (Espinosa-Soto et al., 2004; Álvarez-Buylla et al., 2007; Benítez et al., 2013; Wray, 2007).

Previous reviews have identified at least four main mechanisms capable of altering gene activity, and potentially transforming the architectural topology of GRNs that underlie phenotypic traits: (1) epigenetics or chromatin level regulation of transcriptional expression without changes in the DNA sequence; (2) nonsynonymous coding mutations changing amino acid or mature mRNA sequences, although there are a few studies showing that synonymous mutations may contribute to phenotypic evolution too (Stam and Laurie, 1996; Nackley et al., 2006); (3) cis-regulatory mutations, where changes in the nucleotides of binding sites located on the same DNA strand of the gene they regulate can modify its expression patterns; and (4) copy number mutations, such as gene loss and duplications, involving both coding and cis-regulatory changes (Stern and Orgogozo, 2008; Peter and Davidson, 2010; Gruber et al., 2012).

Altering GRNs by modifying the epigenetic landscape, mutating cis-regulatory elements or changing the structure of trans-regulatory factors may result in the generation of novel phenotypes in plants (Fig. 1; Barrio et al., 2013). To what extent regulatory or coding mutations contribute to phenotypic evolution, however, is an issue that has not been satisfactorily answered yet, as stated above (Wray, 2007; Hoekstra and Coyne, 2007; Carroll, 2008; Stern and Orgogozo, 2008). In the case of plants, integrating the cases in which such types of alterations have been associated to a phenotypic change will contribute toward this aim.

\section{Phenotypic Changes Associated to Epigenetic Variation}

Epigenetics refers to stable heritable changes in gene function without altering the DNA sequence (Riggs and Porter, 1996; Berger et al., 2009) through different mechanisms such as DNA methylation, synthesis of noncoding RNAs and histone modifications (e.g., methylation, acetylation, ubiquitination, phosphorylation, and sumoylation). These epigenetic modifications constitute the epigenetic landscape that regulates chromatin states from a compact to a relaxed status and vice versa (Roudier et al., 2011; SequeiraMendes et al., 2014; see Fig. 1) to adjust the interaction of transcriptional factors or DNA replication proteins with DNA. Recently, there has been an enormous amount of information regarding the fundamental role of epigenetics during the development and growth of living organisms; and Arabidopsis thaliana has been one of the most important model systems used (Grimanelli and Roudier, 2013; Desvoyes et al., 2014; Law and Jacobsen, 2010).

Plant DNA methylation occurs at any cytosine residue and is catalyzed by DNA methyltransferases such as MET1, CMT3, DRM1, and DRM2 (Bartee et al., 2001; Lindroth et al., 2001; Cao and Jacobsen, 2002; Kankel et al., 2003), which can promote DNA methylation after DNA replication or as de novo in small regions of the genome. Therefore, DNA methylation is crucial to genomic integrity maintenance and gene expression regulation (Furner and Matzke, 2011). In this regard, it has been proposed that DNA methylation protects the host genome through silencing of transposable elements (TEs), maintaining centromeric and heterochromatin regions, and silencing imprinting genes (Hirochika et al., 2000; Lippman et al., 2004; Kohler and Grossniklaus, 2005; Zhang et al., 2008). The silencing of a subset of transposons and genes by de novo DNA methylation can be mediated by the RNA-directed DNA methylation pathway, which requires small interfering RNAs (siRNAs) (Matzke and Mosher, 2014). Unlike transposons, DNA methylation of promoter regions normally inhibits transcription, but methylation in coding regions does not generally affect gene expression, although some genes contain regulatory elements in their coding regions, which are also methylated when such genes are silenced (e.g., SUPERMAN and AGAMOUS).

DNA methylation is a stable although reversible epigenetic mark that regulates gene expression during plant development and is heritable across generations. Nonetheless, adaptation processes, external signals or intrinsic factors may induce erasure or modification of this mark at one or more points during plant development, and the inheritance acquired may be modified. This transgenerational epigenetic inheritance in plants usually occurs in response to environmental cues and adaptation processes, generating natural epialleles (Richards, 2008).

Now we know that natural variation exists not only at the DNA sequence level but also at the epigenetic level (e.g., Vaughn et al., 2007; Herrera and Bazaga, 2010). This may be particularly common in plants, and several studies suggest that natural epialleles can cause significant heritable variation that affects 
A

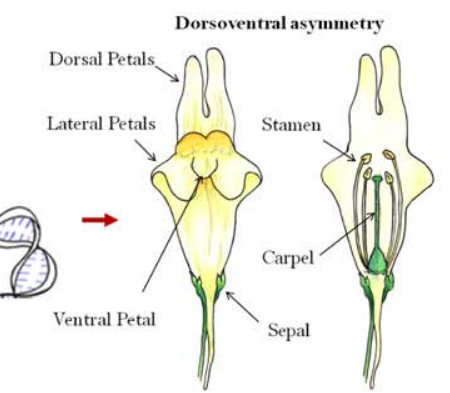

WT Linaria vulgaris

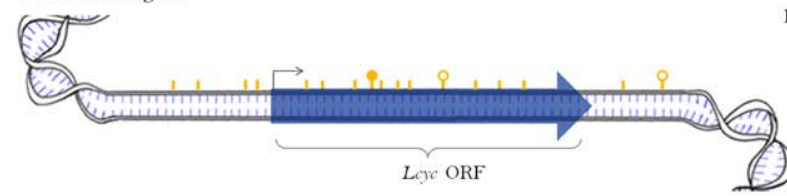

Radial symmetry

Peloric Linaria vulgaris
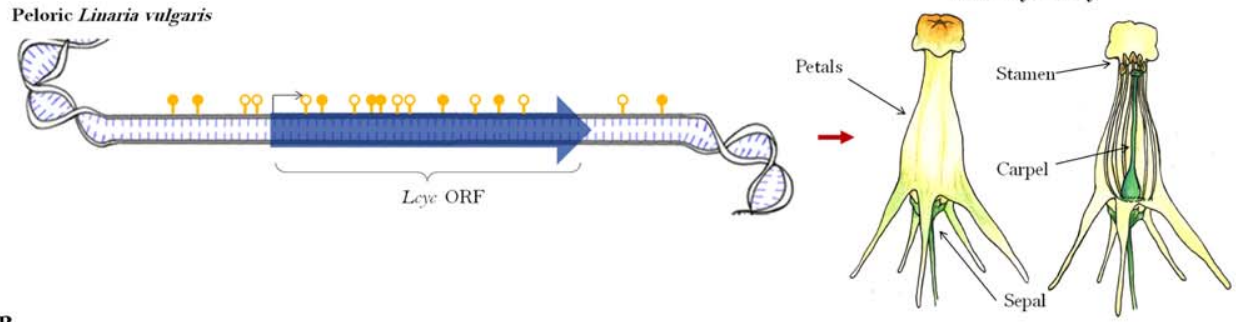

B

Blond orange

(Navelina)

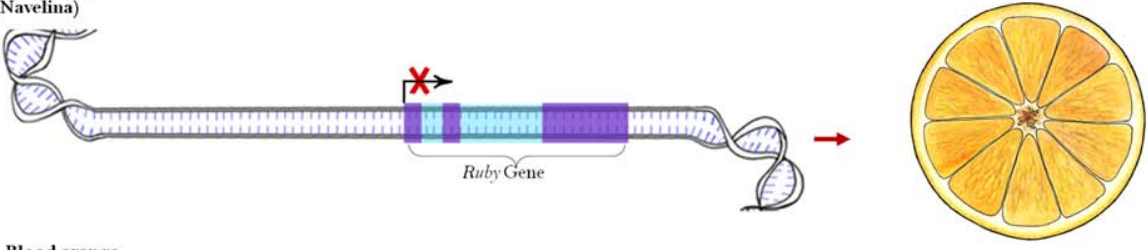

Blood orange

(Moro)

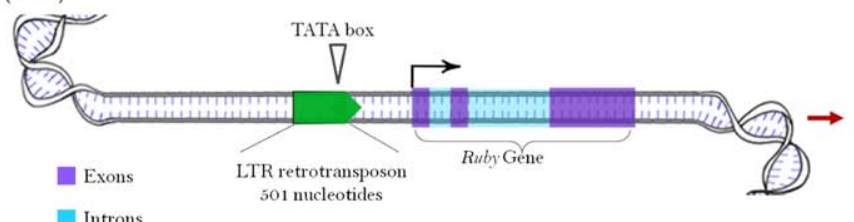

Introns

01 uucleotides

C

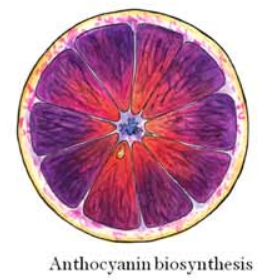

Petunia integrifolia

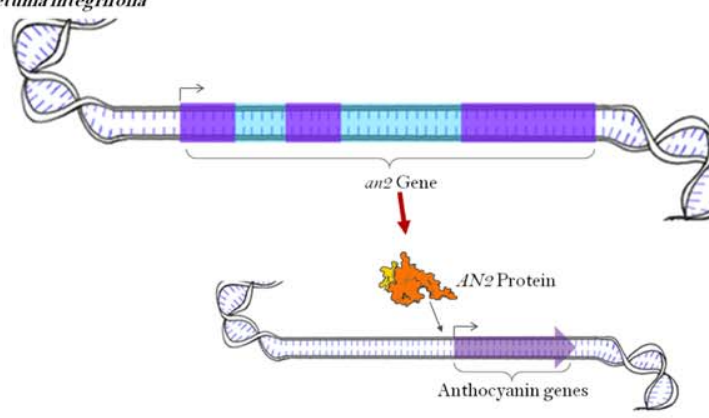

Petunia axillaris
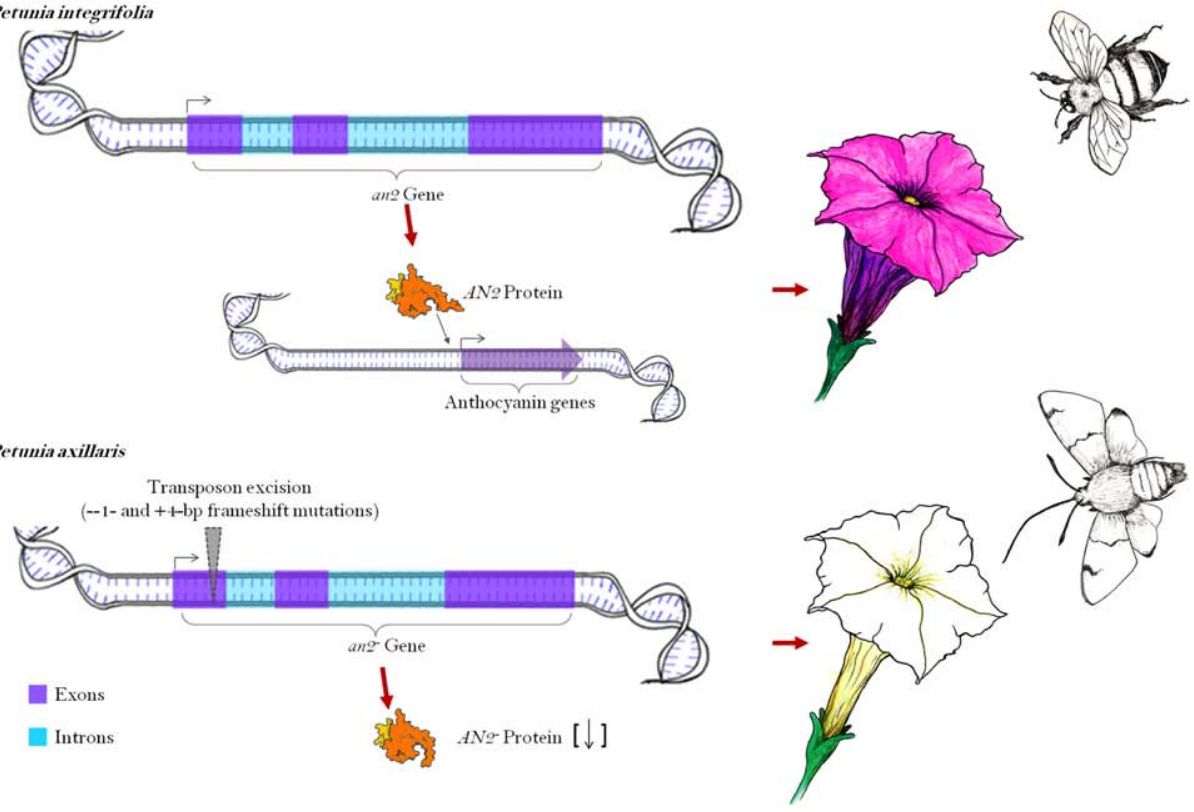

Fig. 1. 
phenotypic traits. Linaria vulgaris, a plant described by Linneaus that could naturally produce two flower morphs: the most common; a bilaterally symmetrical flower but on occasions, a flower with radial symmetry would develop. L. vulgaris was the first documented example of the existence of epialleles that produce morphological alterations depending on the DNA methylation state of the Lcyc gene (Fig. 1A; Table 1). Lcyc is a homolog of the CYCLOIDEA gene from Antirrhinum majus and is involved in dorsoventral asymmetry, therefore, radial flowers are formed when Lcyc is silenced through DNA methylation (Luo et al., 1996; Cubas et al., 1999b). These morphological alterations can have ecological and evolutionary implications because changes in the shape and scent of a flower could alter its pollination syndrome, affecting its reproductive success.

The production of male or female or hermaphrodite flowers in melon (Cucurbita melo) is another example where sex determination depends on epigenetic variation. Melon plants are monoecious producing either unisexual flowers, or both unisexual and hermaphrodite flowers. This feature is correlated with the silencing of the gene CmWIPI through DNA methylation (Table 1). This gene is required to form stamens, therefore, development of female flowers is induced when CmWIPI is silenced (Martin et al., 2009). Plants with unisexual flowers inhibit self-fertilization, generating genetic diversity (Turck and Coupland, 2014).

Finally, experimental DNA demethylation experiments in Arabidopsis thaliana suggest that DNA methylation strongly affects ecologically important plant traits such as mortality, flowering time, plant height, biomass, and very importantly, phenotypic plasticity (Bossdorf et al., 2010). In nonmodel plants like the mangrove Laguncularia racemosa, natural morphological changes have been correlated with variation in methylation patterns (Lira-Medeiros et al., 2010). Populations of this plant grow in contrasting habitats where nutrients and salinity levels vary considerably, leading to significant differences in tree height, tree diameter, leaf width, and leaf area. Lira-Medeiros and collaborators (2010) documented divergent epigenetic profiles between mangrove populations, showing that the genome from plants growing in salt marshes is hypomethylated in comparison with those growing in riversides. CpG-methylation changes, thus, may be associated with environmental heterogeneity and phenotypic plasticity between natural populations or ecotypes, as suggested by similar studies in other forest tree species, such as poplar and eucalyptus (reviewed by Bräutigam et al., 2013).

\section{Phenotypic Alterations in Flower Development}

A central theme in plant evo-devo has been the study of the development of flowers, because these structures are good model systems to investigate the genetic underpinnings and evolutionary consequences of phenomena such as: homeotic alteration of organ identity, changes in size and form of organs as well as modification of other characteristics like color, symmetry, and scent. The effect of individual genes whose activity affects flower organ development as well as flowering time have been studied in a subset of angiosperms, while their interactions in higher order gene regulatory networks have yielded important insights into floral evolution. In the next section, we illustrate some of the salient findings in this area of research.

\section{ABC Model}

Flowers are one of the defining structures of angiosperms and hermaphrodite flowers are organized in four different concentric whorls arranged from the outside to the inside in sepals (se), petals (pe), stamens (st), and carpels (ca). In the late, 1980s, the knowledge attained through the study of floral homeotic mutants in the model plant species Arabidopsis thaliana and Antirrhinum majus enabled the proposal of the ABC model of floral organ specification (Bowman et al., 1991; Coen and Meyerowitz, 1991). The ABC model integrated information from three classes of floral mutants, each one of them lacking adequate expression of a particular gene. This translated into homeotic transformations where two floral whorls were replaced: in "A" mutants, flowers were composed by ca, st, st, and ca; in "B" mutants, flowers had se, se, ca and ca; and in " $\mathrm{C}$ " mutants, flowers had se, pe, pe and se, as well as an indeterminate floral meristem (Bowman et al., 1991). From previous observations, the functions of these genes were inferred and organized in the $\mathrm{ABC}$ model as follows: sepals are specified by the A function alone (genes APETALA1 and APETALA2; AP1 and $A P 2$ ), petals require a combination of $\mathrm{A}$ and $\mathrm{B}$ functions (genes APETALA 3 and PISTILLATA; AP3 and PI), stamens B and $\mathrm{C}$ functions (gene AGAMOUS; $A G$ ), and carpels $\mathrm{C}$ function alone. Additionally, $\mathrm{A}$ and $\mathrm{C}$ function genes mutually repress each other (Coen and Meyerowitz, 1991).

The ABC model rendered a useful heuristic framework that helped establish a link between experimental genetics and evodevo of flower formation, thus stimulating comparative studies of $A B C$ orthologs and their gene expression patterns and correlations with floral morphology across angiosperms (Saedler et al., 2001; Melzer and Theissen, 2011). A mechanistic explanation to the $\mathrm{ABC}$ combinatorial model came several years later when a robust GRN that integrated the $A B C$ genes with other interacting components, was able to recover the observed $\mathrm{ABC}$ gene configurations documented in wild type and mutant flowers (Mendoza and Álvarez-Buylla, 1998; Espinosa-Soto et al., 2004). The overall conservation of the ABC model across

Fig. 1. Changes in transcriptional regulation account for plant phenotypic variation. A: DNA methylation patterns are related to phenotypic shifts among angiosperms, as in the case of Linaria vulgaris, where floral symmetry is changed from bilateral (top) to radial (bottom) as a result of extensive methylation in the Lcyc gene (Cubas et al. 1999b). In addition, the WT flowers of L. vulgaris fully develop only four stamens, while the peloric mutants develop five functional stamens. All methylation sites within the Lcyc locus are represented by filled orange circles; partially methylated sites are represented by empty orange circles; orange sticks represent nonmethylated sites. B: Modifying the regulatory regions of genes may alter the GRNs governing phenotypic traits, as observed with the Ruby gene: a single 501 bp retrotransposon insertion in its upstream sequence increases anthocyanin levels in orange fruit flesh (Butelli et al. 2012). A TATA box present in the retrotransposon facilitates Ruby transcription in blood oranges. C: The trans-regulatory changes may also play a significant role in plant phenotypic evolution by altering protein structure of key transcription factors. Multiple mutations in the coding sequence of AN2 account for the evolution of flower color between Petunia integrifolia and Petunia axillaris: while the AN2 protein of $P$. integrifolia regulates the expression of genes that belong to the anthocyanin pathway, the frameshift mutations in the $P$. axillaris copy, derived from the excision of a transposable element, predicts a truncated protein (Hoballah et al., 2007). It is believed that this regulatory mutation may have contributed to the evolution of the pollination syndrome of $P$. axillaris. 


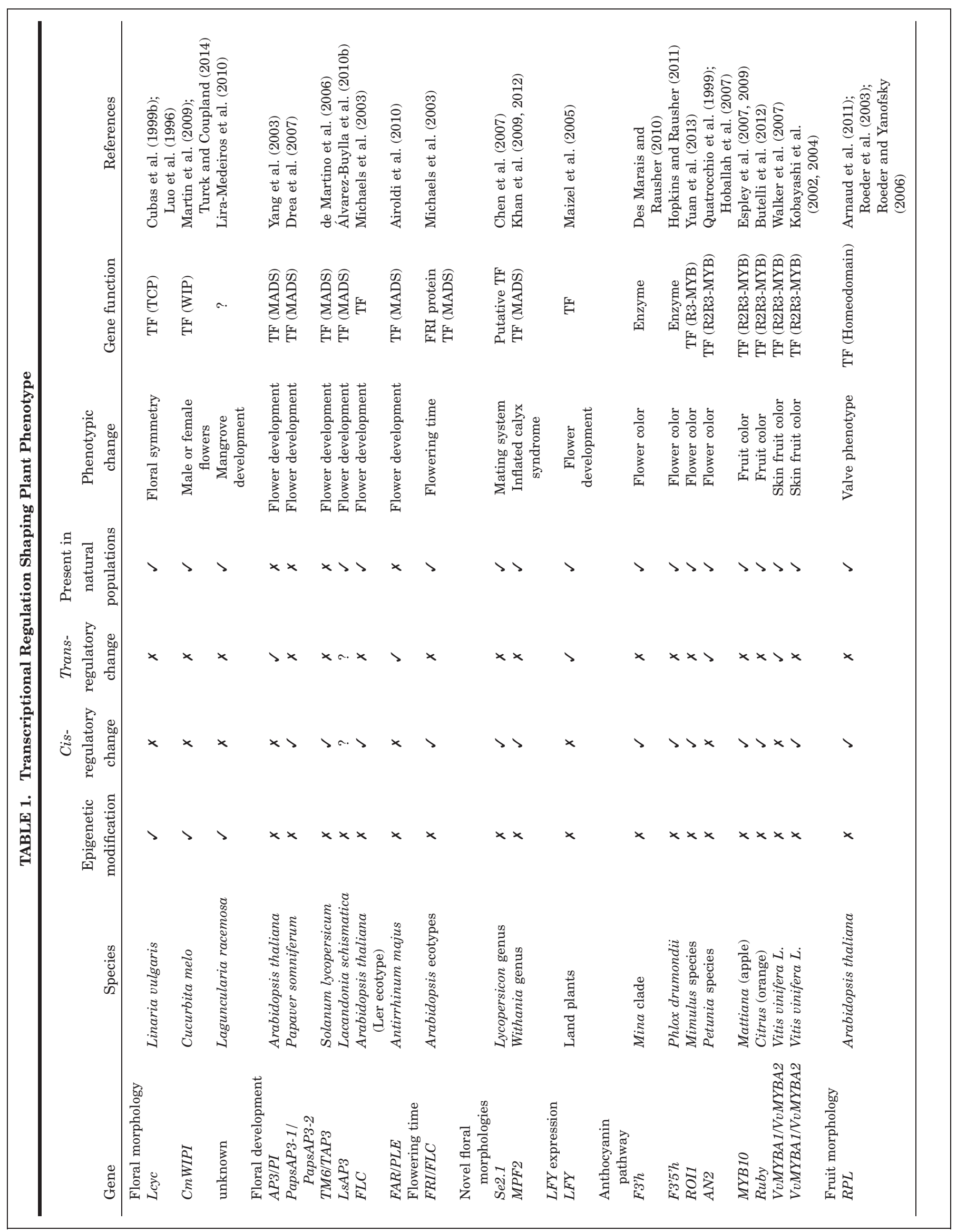


angiosperms is still under debate, while analyses of recent developmental genetics studies in A. thaliana raise questions about some of the main tenets of the $\mathrm{ABC}$ model, even in the realm of research conducted in this model species (Prunet and Jack, 2014). In this context, GRN approaches will aid in generating testable hypotheses across flowering plants. In contrast, an overall widespread conservation of the $\mathrm{ABC}$ genes has been found across distantly related flowering plants; this is probably due to their molecular evolution being restricted by the GRN of which they are part. Such restrictions in a canonical GRN could have been formed during early stages of angiosperm evolution and thus explain the overall conservation of the $\mathrm{ABC}$ genes among many angiosperms (Davila et al., 2014).

\section{MADS Box Genes}

The $\mathrm{ABC}$ genes encode transcription factors and all but one (AP2) belong to the MADS-box gene family (Riechmann and Meyerowitz, 1997): AP1, PI, AP3, and AG. MADS-box genes participate in all major aspects of plant development although they have been mainly studied in specifying floral organ identity (Smaczniak et al., 2012). MADS-box type II proteins possess four domains (MIKC), so they are referred to as MIKC proteins: the M represents an amino terminal domain that binds DNA, I is an intervening region involved in DNA binding and protein-protein interaction, $\mathrm{K}$ domain is involved in protein-protein interactions (Yang and Jack, 2004), and the C terminal domain is implicated in transactivation and higher order MADS-box protein interactions (Egea-Cortines et al., 1999; Honma and Goto, 2001). Since the 1990s, hybrid proteins interchanging MIKC domains were generated between AP1, AP3, PI, and AG, showing that the MADS domain does not specify for their biological activity while the carboxyl region can contribute to DNA binding specificity (Krizek and Meyerowitz, 1996; Riechmann and Meyerowitz, 1997). To recognize and bind to the CArG boxes present on target DNA, MADS proteins form dimers, either homo or heterodimers, and tetrameric protein associations to carry out their function as transcriptional regulators. Furthermore, this gene family has undergone lineage-specific changes, some related to extensive duplication and subfunctionalization of genes through mutations in their coding or noncoding sequences (Saedler et al., 2001). Such mutations have been linked to the origin of morphological novelties, particularly in flowers (Khan et al., 2012; Gramzow and Theißen, 2013).

It has been shown that $\mathrm{ABC}$ genes are required, but are not sufficient, to specify floral organ identity (Álvarez-Buylla et al., 2010a). They need, at least, the activities of another four closely related MADS-box genes, SEPALLATA1/2/3/4 (SEP1/2/3/4; dubbed "E" function genes), to develop floral organs; the inclusion of these genes as necessary for floral development resulted in what is known as the "floral quartet" model (Honma and Goto, 2001; Pelaz et al., 2001; Theißen and Saedler, 2001). According to the ABCE modified model in Arabidopsis, sepals are specified by the combination of the expression of AP1/AP2 and SEP genes; petals by the expression of AP1/AP2, AP3, PI, and SEP; stamens by the expression of AP3, PI, AG, and SEP and carpels by the expression of $A G$ and $S E P$ (Pelaz et al., 2000; Fig. 2A).

The $\mathrm{B}$ class genes $(A P 3$ and $P I)$ have received special attention, as petals are considered important structures for pollinator attraction and, as such, their diverse architecture has been correlated 


\section{A Arabidopsis thaliana}

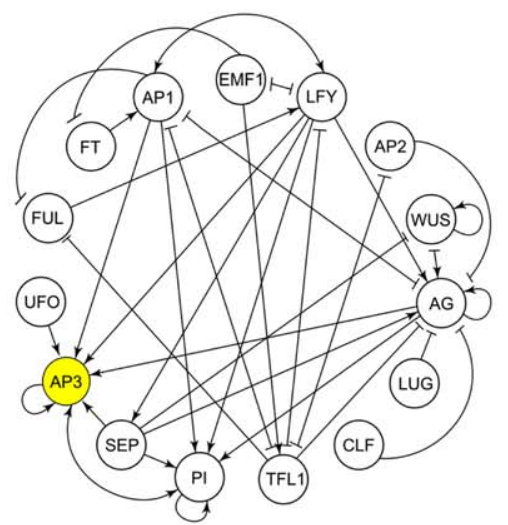

B Petunia

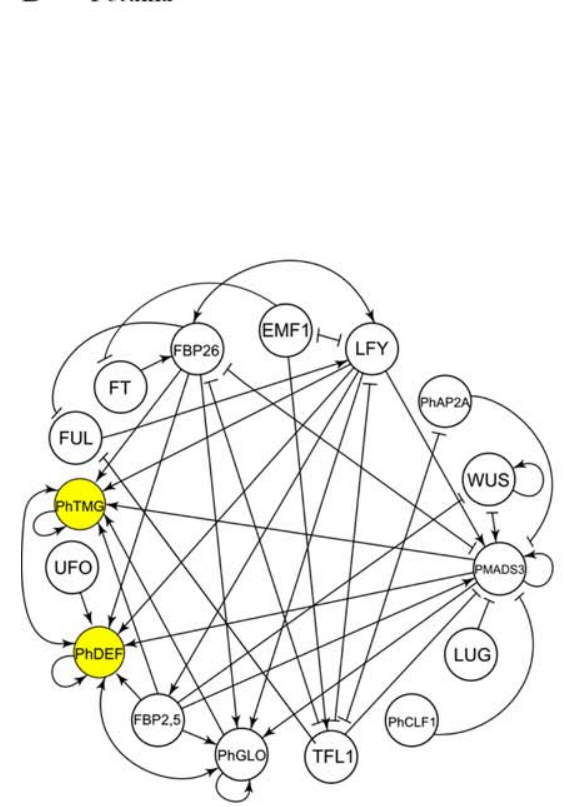

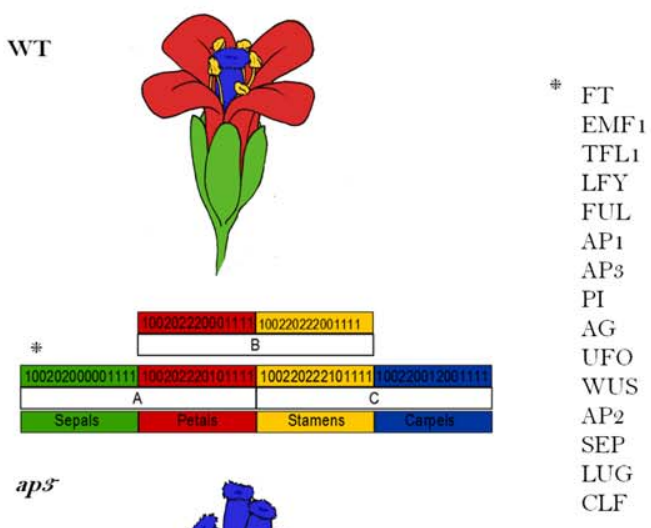

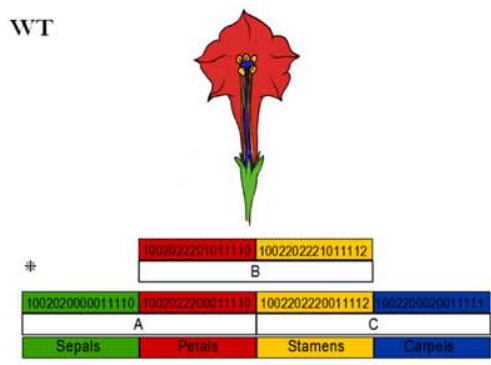

* FT

EMF 1

TFL 1

LFY

FUL

FBP26

PhDEF

$\mathrm{PhGLO1,2}$

pMADS3

UFO

WUS

$\mathrm{PhAP} 2 \mathrm{~A}$

$\mathrm{FBP} 2,5$

LUG

$\mathrm{PhCLF}_{1,2}$

PhTM6

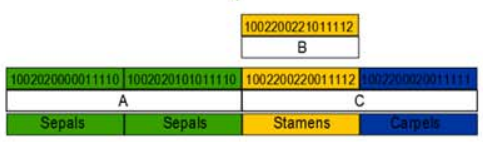

phtmo/phdef-

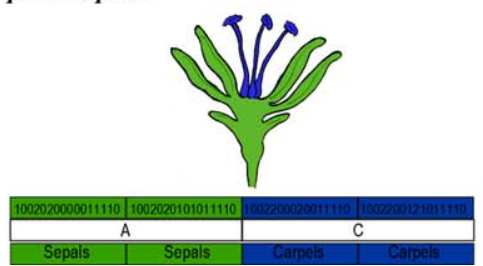

Fig. 2. Corresponding GRN models to floral phenotypic changes. A: The GRN for Arabidopsis floral organ fate determination, according to Espinosa-Soto et al. (2004) and Álvarez-Buylla et al. (2007). The topology of the network shows the regulatory interactions between node pairs, with activations as arrowheads and repressions as blunt-end lines. The basins of attraction that lead to floral primordial cell types are shown in green (sepals), red (petals), yellow (stamens), and blue (carpels). Each attractor is defined for WT and ap3 ${ }^{-}$flowers as the genetic steady-state combination of all genes represented in the network, listed in the figure with their corresponding order, established by three levels of expression: 0 (no expression), 1 (intermediate level of expression) and 2 (overexpression). B: The GRN for Petunia floral organ fate determination, as reconstructed by Espinosa-Soto et al. (2004). The topology and logical rules are the same as the Arabidopsis GRN. In Petunia, nonetheless, two Bclass genes govern the development of petals and stamens: PhDEF and PhTM6. In phdef mutants, functional stamens are observed but in the double mutants phtm6 $6^{-}$phdef stamens do not develop. The yellow nodes of both networks indicate which genes are turned off in floral mutants. 
with the adaptive radiations documented in many angiosperm lineages (Irish, 2009). Moreover, several independent duplications have taken place within the AP3 and PI genes throughout the angiosperms (Kim et al., 2004; Hernández-Hernández et al., 2007; Mondragón-Palomino et al., 2009). Functional studies in different angiosperms encompassing basal angiosperm, nonmodel eudicot, and monocot species indicate variations in the expression sites of B genes with implications on flower architecture (Kanno et al., 2007; Mondragón-Palomino and Theissen, 2009), as it has been assumed that MADS-box genes exert their function where they are expressed (nonetheless, Urbanus et al., 2010 demonstrated that $A G$ is capable of moving through cell layers). In this section, we review various examples where changes in the spatial expression of a particular transcription factor (in these cases, MADS-box genes) have a direct impact on flower morphology.

In Arabidopsis, AP3 and PI exert their function as obligate heterodimers that bind to DNA (Bowman et al., 1989; Goto and Meyerowitz, 1994; Jack et al., 1992). Protein-protein binding occurs by means of the $\mathrm{K}$ domain, which does not show conservation at the primary structure level; nonetheless, the secondary structure is preserved in three amphipathic $\alpha$-helices referred to as K1, K2, and K3 (Álvarez-Buylla et al., 2000). It has been shown that in the 80 amino acid region covered by the $K$ domain, there are several heptad repeats (a and $d$ im bold abcdefg)n in which the bold positions are occupied by hydrophobic amino acids necessary to form the $\alpha$-helices (Yang et al., 2003; Gramzow and Theissen, 2010). Yang and collaborators (2003) demonstrated that the ability to form heterodimers between AP3 and PI is fundamental to perform their function during plant development. Specifically, they found that the critical amino acids for this protein-protein interaction are located in the hydrophobic regions of K1 and K2 domains and the hydrophobic region between them. When these amino acids are mutated, they cause defects in AP3/PI heterodimerization in yeast twohybrid experiments and, correspondingly, in the phenotype of wild-type and mutant plants overexpressing these proteins in Arabidopsis.

In Papaver somniferum, a basal eudicot, AP3 is duplicated into PapsAP3-1 and PapsAP3-2. Each paralog has a different expression pattern. PapsAP3-1 is highly expressed in petals and stamens throughout floral development and weakly expressed in sepals and carpels during later stages. In contrast, PapsAP3-2 is initially expressed in stamen primordia (stage 4) and petal primordia (stage 5); but from stage 8 onward, this gene is expressed in all floral organs (Drea et al., 2007). Silencing of PapsAP3-1 results in homeotic transformation of petals to sepaloid organs, while inhibiting the expression of PapsAP3-2 causes stamens to be transformed into carpeloid structures; stamen and petal homeotic transformations are observed when both genes are silenced simultaneously (Drea et al., 2007).

In tomato, there are two paralogs for AP3 (TM6 and TAP3) and for PI (TPI and TPIB). de Martino et al. (2006) found that only the TAP3 loss-of-function mutant shows a complete conversion of petals into sepals and stamens into carpels; the other B loss-of-function mutants (TM6, TPI, and TPIB) only affect stamen development (de Martino et al., 2006; Geuten and Irish, 2010). The differences in function of the AP3 orthologs could be partially attributed to the level of expression of the genes, as overexpression lines confer a similar, but not identical, degree of tap3 mutant rescue (de Martino et al., 2006).
In Antirrhinum majus, there are two paralogs that fulfill the $\mathrm{C}$ function (FARINELLI and PLENA; FAR and PLE). Overexpression of FAR or PLE yields different flower morphologies in Arabidopsis. PLE has the same phenotypic effect as $A G$ (a flower with whorls transformed into ca, st, st, ca) and FAR converts petals into stamens but does not affect the fate of sepals (Airoldi et al., 2010). Airoldi and collaborators (2010) showed that a single amino acid deletion in the K3 domain (important for protein-protein interaction) of FAR (Q173) or its introduction in the K3 domain of AG is sufficient to define the reproductive organ fate. The presence of Q173 correlates with male organ development, and its absence with both, the development of male and female organs (Airoldi et al., 2010). Moreover, these authors also demonstrate the importance of considering protein-protein interactions to explain biological activity. In this case, AG interacts with the MADS-box proteins SEP1, SEP2 and SEP3 in stamen and carpel development while FAR only interacts with SEP3. SEP3 is not expressed at early developmental stages in sepals and the authors showed that the inability of FAR to develop carpels in the first whorl not only depends on its amino acid content but also on the expression pattern of SEP3, highlighting the importance of considering the underlying GRNs to understand how such molecular alterations map onto the phenotype.

\section{Lacandonia}

Lacandonia schismatica (Triuridaceae) is a monocotyledonous species endemic to the Mexican Lacandon rainforest that, along with Lacandonia brasiliana, are the only examples of an angiosperm with bisexual flowers where the stamens are in the center of the flower surrounded by carpels (Martínez and Ramos, 1989; Melo and Alves, 2012). In L. schismatica, this phenotype is fixed in natural populations (Vergara-Silva et al., 2003). Developmental genetics studies have shown that while this plant has only one copy each of the AP3 and PI orthologs, the unique arrangement of the reproductive whorls in $L$. schismatica depends on a the shift of the spatio-temporal expression patterns of LsAP3 (AP3 ortholog) to the center of the developing flower primordium (Álvarez-Buylla et al., 2010b). In contrast, the overall expression pattern of the other $L$. schismatica floral homeotic genes that participate in stamen and carpel development ( $L s P I$ and $L s A G$ ) is very similar to the expression patterns that have been reported for Arabidopsis orthologs (Álvarez-Buylla et al., 2010b). Thus, $L$. schismatica provides an extreme example of how a shift in the physical domain where a gene is expressed can yield a unique phenotype, without obvious modifications in its interacting partners ( $L S P I$ and $L s A G$ ). It is still not known if the displacement of $L s A P 3$ expression is due to changes in the cis-regulatory sequences of the gene, while the rest of the GRN is conserved, or if it is due to alterations in the trans-acting factors that regulate LsAP3 expression (probably, the transcription factor $L E A F Y(L F Y)$ and its co-activator UNUSUAL FLORAL ORGANS (UFO), as documented in Arabidopsis; Chae et al., 2008; Parcy et al., 1998; Weigel and Meyerowitz, 1993).

\section{Flowering Time}

Flowering time is one of the most important events in the life cycle of plants, as it ensures reproductive success. There are winter- and summer-annual Arabidopsis flowering habit ecotypes that depend on the variation in the expression of FRI (FRIGIDA) 
and FLC (FLOWERING LOCUS C). FRI is a positive regulator of FLC, a MADS-box gene that represses the expression of floral activators. It has been shown that FLC expression is low in summer-annual strains and high in winter-annual Arabidopsis plants (Michaels and Amasino, 1999; Sheldon et al., 2000). Michaels and collaborators (2003) introduced a functional allele of FLC in two summer-annual strains (Da (1)-12 and Shakhdara) and were able to restore winter-annual habit. Moreover, they also demonstrated that the low level of expression in the Ler ecotype is caused by an insertion in the first intron of FLC.

\section{Novel Floral Morphologies}

Structural change in the gynoecium of flowers, more specifically in the stigma, i.e., the pollen-receiving tip of carpels, has also been linked to cis-regulatory mutations. The tomato genus Lycopersicon (tomato group) is composed of nine species that exhibit a wide range of mating systems: from the ones that are exclusively allogamous, forced to cross-pollinate, to the ones that are obligate autogamous and self-pollinated species, including other intermediate states (Rick, 1988). Several reports have suggested that stigma length correlates with the evolution of either of these mating systems: allogamous species have exerted stigmas, while inserted stigmas are characteristic of autogamous species. It has been observed that se2.1, a major QTL and a putative transcription factor, is responsible for the phenotypic variation of this trait, and some studies have suggested that mutations on this gene may account for the evolution of mating systems in the Lycopersicon genus (Bernacchi and Tanksley, 1997; Fulton et al., 1997; Tanksley and Loaizafigueroa, 1985). Chen and collaborators (2007) reported that the transition from allogamy to autogamy is accompanied by a mutation in the se2.1 promoter region, which explains its down-regulation during flower development in autogamous species.

Finally, an additional example of evolutionary studies in flower development, comes from the Solanaceae family, where the calix (i.e., the sepals) exhibits many different morphologies ranging from a small sepal ring in Tubocapsicum anomalum to the inflated calyx syndrome (ICS) observed in 11 different species of Withania (Khan et al., 2012). In the ICS, sepals resume growth after pollination, encapsulate the mature fruit and give rise to a balloon-like structure. Previous studies have shown that the expression of a MADS-box transcription factor (MPF2, a paralog of the MADS box gene AGL24 in Arabidopsis; Khan et al., 2012) in the calyx is a prerequisite for ICS formation in the species Physalis pubescens (He and Saedler, 2005, 2007). All Withania species have two orthologs of MPF2: one that is expressed in vegetative and flower tissues (MPF2-like-A) and another one that is only expressed in vegetative tissues (MPF2-like-B) (Khan et al., 2009). The expression divergence between paralogs (in this case, MPF2-like-A and MPF2-like-B) had been correlated with modifications in cis-regulatory regions (Chaudhary et al., 2009; Goode et al., 2011). By analyzing the cis-acting elements of Withania genes, it was found that MPF2-like-A regulatory regions lacks an ARE (Auxin Response Element, binding site for Auxin Response Factors) binding site in the $1^{\text {st }}$ intron necessary to suppress the expression in the calyx (Khan et al., 2012). Furthermore, the MPF2-like-B promoter is devoid of a CArG-box (binding site for MADS proteins) near the transcriptional start site required for its expression in sepals (Khan et al., 2012). This reciprocal loss of cis-regulatory elements is characteristic of divergence events after duplication (Khan et al., 2012).

In contrast to Withania, Tubocapsicum does not have an MPF2-like-A gene and only features an MPF2-like-B. This gene is expressed in all floral tissues and has a CArG box element (Khan et al., 2009). The lack of MPF2-like-A in Tubocapsicum suggests a correlation between ICS formation and MPF2-like-A expression in Withania. Moreover, analysis of overexpression lines of Withania MPF2-like-A and MPF2-like-B genes and Tubocapsicum MPF2-like-B gene show that only the overexpression of MPF2-like-A produces flowers with a large-sepal phenotype in Arabidopsis (Khan et al., 2009). These studies demonstrate that the variation of gene expression in MPF-like genes influence ICS formation and underlie the phenotypic variation in sepal development found within the Solanaceae family. The function of the ICS is not clear; however, it could facilitate wind dispersal of the fruits (Knapp, 2002), provide a humid microclimate (Khan et al., 2009) or have a protective role in early developmental stages of some organs (He and Saedler, 2007).

\section{LEAFY Expression in Plant Development}

$L F Y$ is a plant specific transcription factor that has been found in mosses, ferns, gymnosperms and angiosperms; in the latter it regulates flower development (Moyroud et al., 2010). LFY orthologs have two conserved regions in the $\mathrm{N}$-terminal and C-terminal domains in all land plants surveyed to date (Maizel et al., 2005; Moyroud et al., 2009). To test functional conservation, Maizel and collaborators (2005) isolated $L F Y$ orthologs from mosses and other land plants and introduced them into a lfy mutant from Arabidopsis, finding a direct correlation between the degree of complementation of the $L F Y$ phenotype and the phylogenetic distance from angiosperms. The $L F Y$ ortholog from the moss Physcomitrella patens was the only gene unable to rescue the lfy mutant (Maizel et al., 2005). In contrast, one amino acid change in the DNA binding domain of the moss gene was sufficient to partially complement a lfy Arabidopsis mutant phenotype, indicating that the moss ortholog has different DNA binding specificities.

\section{Anthocyanin Pathway}

Anthocyanins are plant pigments (orange, pink, red, blue, and purple) that are present in all tissues of higher plants; these pigments are synthesized by means of the flavonoid pathway that is highly conserved across angiosperms (Holton and Cornish, 1995). There are three precursors that require at least six different enzymes to produce all anthocyanin pigments. Of interest, there is a coordinated gene regulation of the different pathways at the level of transcription in all the species studied (Sobel and Streisfeld, 2013). The transcriptional complex that regulates gene expression is made up of proteins from three large transcription factor gene families: R2R3-MYB, basic helix-loop-helix (bHLH) and WD40 repeat (Sobel and Streisfeld, 2013). It has been shown that the specificity of the complex is determined by the proteins from the R2R3-MYB family while these transcription factors tend to be tissue specific in such a way that they affect anthocyanin production in a localized manner.

In the following section, we will review examples where changes in flower and fruit color rely either on mutations in 
regulatory (cis) or coding (trans) regions in different genes, many of them are in R2R3-MYB transcription factor genes.

\section{Variation in Flower Color}

Reproductive isolation results from prezygotic and postzygotic barriers to prevent gene flow between populations and one of the most important prezygotic barriers is pollinator isolation (Hopkins and Rausher, 2012). In recent years, it has been strongly suggested that variation in flower color is somehow related with changes in pollinator behavior (Rieseberg and Blackman, 2010; Hopkins, 2013).

In an attempt to identify the relative importance of regulatory vs. coding mutations in the evolution of flower color, it has been found that regulatory changes play a significant role not only in generating phenotypic variation but also in favoring certain reproductive barriers in plants (Durbin et al., 2003; Rieseberg and Blackman, 2010). Des Marais and Rausher (2010), for instance, performed gene expression assays and plant transformations experiments to determine the genetic basis of color shift in the hummingbird-pollinated flowers of two morning glory species: Ipomoea quamocitl and Ipomoea coccinea. Both of these belong to a monophyletic group called the Mina clade, which comprises 16 species, all of which are red or orange-flowered. Nevertheless, it is believed that blue/purple flowers, most often pollinated by bees, represent the ancestral state for the Ipomoea genus (Streisfeld and Rausher, 2009). Thus, it has been proposed that a flower color transition, from blue or purple to red, has occurred, bringing ecological consequences along the way because pigments are visual signals for some animals.

Flower pigmentation in morning glories appears to be controlled by alternate precursors of the same anthocyanin biosynthetic pathway: blue-flowered species produce cyanidin whereas some red-flowered species synthesize pelargonidin (Zufall and Rausher, 2004; Streisfeld and Rausher, 2009). After revealing that gene expression of flavonol-3'-hydroxylase, $F 3^{\prime} h$, an enzyme that blocks the cyanidin branch of the anthocyanin pathway, is modified in red flowers, Des Marais and Rausher (2010) examined whether cis or trans changes were responsible for the phenotypic shift from blue to red flowers in the Mina clade, and discovered that it is caused, at least in part, by a cis-regulatory mutation in the promoter of $F 3^{\prime} h$.

The Texas wildflower (Phlox drummondii) has also been the focus of similar discoveries, remarkably because it has been demonstrated that divergence of floral color increases prezygotic isolation among its populations (Levin, 1985). Hopkins and Rausher (2011) found that the shift from light-blue to dark-red flowers in $P$. drummondii is related to variation in the expression of two genes from the anthocyanin biosynthetic pathway: flavonoid 3', $5^{\prime}$-hydroxylase $\left(F 3^{\prime} 5^{\prime} h\right)$ and an R2R3-MYB related transcription factor. Based on analyses of allele-specific expression in heterozygous individuals, they were able to identify that both genetic changes contributing to flower color change involve cis-regulatory mutations.

A different study by Yuan et al. (2013) regarding cis-regulatory evolution as the origin of flower color variation between closely related species has been conducted in the hummingbirdpollinated Mimulus cardinalis and the bee-pollinated Mimulus lewisii. In contrast to the red flowers of M. cardinalis, rich in carotenoids and anthocyanins, the pink flowers of $M$. cardinalis have small amounts of anthocyanins while carotenoids are absent in their petals. In a previous experiment, it had been identified that a higher anthocyanin concentration in M. cardinalis was due to a single QTL (Bradshaw et al., 1995). Through genetic mapping, mutagenesis assays, and transgenic research, Yuan et al. (2013) managed to relate the anthocyanin QTL to a R3-MYB repressor called ROI1 and discovered that cis-regulatory mutations in this gene are responsible for pigment variation between M. cardinalis and M. lewisii.

Finally, there is an example where changes in trans acting factors underlie floral morphological variation. Bumblebeepollinated Petunia integrifolia and hawkmoth-pollinated Petunia axillaris are closely related species with purple and white flowers, respectively (Fig. 1C). Quatrocchio et al. (1999) and Hoballah et al. (2007) identified a key R2R3-MYB regulator that controls flower color differences between both plants called AN2. The authors from the latter article noticed that white-colored flowers of $P$. axillaris evolved as a consequence of multiple nonsense and frameshift mutations in the coding region of $A N 2$, most likely generated by a transposable element (Hoballah et al., 2007). Furthermore, to investigate the role of $A N 2$ as a major determinant of pollinator attraction, they introgressed the functional $P$. integrifolia AN2 variant into a $P$. axillaris background, transforming white flowers into purple ones, and tested pollinator preference. Surprisingly, restoring AN2 function through purple transgenic flowers of $P$. axillaris resulted in a major pollination syndrome shift, as hawkmoths showed a preference for the wild-type white flowers over the transformed flowers, whereas bumblebees acted in the opposite way (Hoballah et al., 2007).

\section{Variation in Fruit Color}

Fruits are the structures derived from flowers that contain the fertilized ovules that develop into seeds. Fruit morphology is very diverse, ranging from dry and hard capsules that expel the seeds when mature to succulent tissues that are eaten by vertebrates who disperse the seeds, as well as indehiscent fruits, among many variations.

The underlying causes of shifts in flesh and skin color of fruits have also been researched. Red-fleshed apple varieties from Central Asia with high anthocyanin content contrast with the white color flesh observed in most apples. In apples, the MYB10 (R2R3MYB) gene regulates flesh color, and it has been observed that high expression levels of MYB10 transcript correlate with a higher anthocyanin content in the flesh (Espley et al., 2007). Differences in transcriptional regulation of MYB10 appear to be caused by regulatory changes: Espley et al. (2009) identified a 23-bp repeat motif in the promoter of MYB10 specific to redfleshed apples, which leads to an increase in MYB10 expression levels.

In a similar investigation, Butelli et al. (2012) explored the genetic and molecular basis of color shift in oranges. Orange varieties and hybrids present a wide range of phenotypic differences. The blood orange (Citrus sinensis), for instance, has crimson colored flesh and presumed health-promoting properties due to its high anthocyanin content. As in flowers, R2R3-MYB transcription factors regulate the anthocyanin biosynthetic pathway and govern pigment intensity in fruits. Butelli et al. (2012) managed to isolate an R2R3-MYB gene named Ruby from blood orange tissue and, through expression analysis, found a clear correlation between levels of Ruby transcript and levels of anthocyanin in fruit flesh among 15 varieties of blond and blood oranges, 
higher levels of expression were observed in blood oranges whereas in blond oranges Ruby expression was not detected (Fig. 1B). Afterward, they cloned, sequenced, and isolated the Ruby gene from the genomic DNA of blood and blond varieties, discovering that in blood oranges there was a large DNA insertion in the upstream region that was responsible for controlling the expression of Ruby (Butelli et al., 2012).

Fruit skin color change has also been documented within species. Perhaps one of the best well-known examples is the domesticated grapevine (Vitis vinifera L.), where the color of grape skin is determined by the accumulation of anthocyanins in several cell layers. Because wild vines have dark-colored berries, it is believed that white-colored flesh varieties are the result of mutations in the anthocyanin biosynthetic pathway, specifically in MYB regulators. Grapevine has two paralogous copies of R2R3MYB transcriptional regulators called VvMYBA1 and VvMYBA2 (Kobayashi et al., 2002). In an early approach, Kobayashi et al. (2004) examined the molecular basis of color variation in grapevines and found a retrotransposon-induced mutation in the promoter of $V v M Y B A 1$ related with transcription interruption of this gene, which they associated with a loss of pigmentation in white cultivars.

Although Kobayashi et al. (2004) argue that the loss of pigmentation in skin color of grapevines is due to changes in the promoter of the gene $V v M Y B A 1$, Walker et al. (2007) focused on the transcription factor $V v M Y B A 2$ and discovered that the white berry allele is inactivated by two nonsynonymous changes. Therefore, white grapes may have arisen through regulatory and coding mutations in the MYB regulators $V v M Y B A 1$ and $V v M Y B A 2$, rendering both genes inactive.

\section{Fruit Morphology in the Brassicaceae Family}

In Arabidopsis, two modified carpels or valves protect the developing seeds; these valves are joined by a structure called the replum. At maturity, the valves detach from the replum to open the fruit and disperse the seeds (Roeder and Yanofsky, 2006; Roeder et al., 2003). Roeder and collaborators (2003) identified a homeodomain transcription factor called REPLUMLESS (RPL) important in the development of the valve/replum boundary (Marsch-Martínez et al., 2014). The replum morphology varies considerably in the Brassicaceae family: while in Arabidopsis the replum has ten cell files that separate the valves, in its closest genus (Brassica $s p$.) the replum is very compact and the valves are closer together. The expression level of RPL can explain the difference in valve phenotype between Arabidopsis and Brassica. Moreover, a single nucleotide change in the cis-acting elements of the RPL gene is sufficient to convert the Arabidopsis fruit phenotype into a Brassica fruit phenotype, and vice versa (Arnaud et al., 2011).

\section{Floral Scent}

Flowers of many plant species produce floral scent, a mixture of low molecular weight compounds that act as pollinator attractants. In some plant species, enzymatic activities and emission of some floral scent compounds are regulated at the transcriptional level (Dudareva et al., 1998). Petunia axillaris is an annual herbaceous plant native to South America with strong scented flowers pollinated by a hawkmoth. In contrast, the closely related $P$. exerta displays scentless bright red flowers pollinated by hum- mingbirds. To dissect the genetic basis of fragrance production differences between $P$. axillaris and $P$. exerta, Klahre et al. (2011) performed hybrid crosses and identified two QTLs. One of these loci is the ODORANT1 (ODO1) gene, an R2R3-MYB transcription factor responsible for regulating benzenoid volatile production in Petunia flowers (Verdonk et al., 2005). Sequencing of the gene's promoter from several species and assaying expression levels in the F1 hybrids suggested that the differences in gene expression are explained by a cis-acting polymorphism in ODO1 (Klahre et al., 2011).

\section{Leaf Development}

Leaves are specialized organs where photosynthesis takes place in many plant species. In angiosperms, they can have a simple (with an undivided blade) or compound (with subdivided blade) structure and both types of leaves can be found in related species or even in the same individual (heterophylly) suggesting the different types of leaf morphology could have evolved recently (Chen et al., 1997) and that they can develop contrasting morphologies based on environmental cues. Among the genes that have been shown to alter leaf development are the homeodomain transcription factor knotted-like (KNOX) genes. KNOX genes are classified in two groups, based on expression patterns and sequence similarity within the homeodomain (Hay and Tsiantis, 2010). Here, we give examples of the function of class I genes KNOX1, STM (SHOOTMERISTEMLESS), and TKN1 (TOMATOKN1), in leaf development (Hay and Tsiantis, 2006, 2010).

In model species with simple leaves, like maize and Arabidopsis, KNOX genes are expressed only in meristem cells of the SAM and are excluded from the leaves; in contrast, in many species that have compound leaves (tomato, among others), KNOX genes are expressed both in the SAM and in leaf primordia cells (Hareven et al., 1996; Piazza et al., 2010). It has been shown that transgenic expression of any member of Class 1 KNOX genes in the leaves of $A$. thaliana yield lobed leaves (Piazza et al., 2010; Shani et al., 2009). Moreover, other Arabidopsis species, like A. lyrata, bare compound leaves and express KNOX genes in the developing leaf primordia (Piazza et al., 2010). Additionally, other species of the Brassicaceae family, like Cardamine hirsute, have compound leaves and present STM expression in older leaf primordia; if KNOX expression is reduced using weak iRNA lines, the plants develop fewer leaflets per leaf (Hay and Tsiantis, 2006).

Moreover, the aquatic Brassicaceae species, Neobeckia aquatica, bears both simple and compound leaves. Leaf development in this species depends on light intensity which in turn, regulates KNOX1 expression: under low light intensity, plants develop compound leaves and KNOX1 is expressed; in contrast, under high light intensity, plants develop simple leaves and KNOX1 is repressed (Bharathan et al., 2002).

Finally, leaf margin dissection patterns, which range from smooth to serrated or lobed, represent a well-studied trait that has evolved multiple times across land plants, and for some cases it has been correlated with the modification of certain loci involved in complex regulatory networks. One of such loci is the homeobox REDUCED COMPLEXITY (RCO) gene. RCO is specifically expressed in leaves, where it is required for leaflet development. When deleted, the RCO mutants ( $r c o)$ exhibit leaf simplification, from dissected into simple lobed leaves (Vlad et al., 2014). Within the Brassicaceae, some naturally evolved changes in leaf shape may be attributed to differences in the 
regulation of $R C O$, as suggested by a comparative analysis between the sister species Capsella rubella and Capsella grandiflora (Sicard et al., 2014). In their study, Sicard et al. (2014) show that an allelic variant at $R C O-A$ is related to leaf shape variation in Capsella, and they later discover that cis-regulatory variation at this locus underlies naturally occurring leaf shape changes by responding differently to ambient temperature.

\section{Leaf Morphogenesis}

Angiosperm mature leaves are typically flat with two anatomically distinct faces that correspond to the upper (adaxial) and lower (abaxial) side of the leaf. It has been proposed that the development of a flat lamina was a key event in leaf evolution as it enables this organ to capture light more efficiently and to generate complex organ morphologies, such as stamens (Yamaguchi et al., 2012). Arabidopsis leaf growth occurs in cells located in the intersection of abaxial and adaxial zones and partially depends on the participation of genes of two subfamilies of the WUSCHEL (WUS) homeobox (WOX) transcription factor family: WOX1/STF and WOX3/PRS (Yamaguchi et al., 2012; Fukushima and Hasebe, 2014). In Arabidopsis, the 15 members of the WOX family are involved in different aspects of plant development (Mayer et al., 1998; Haecker et al., 2004; Park et al., 2005; Sarkar et al., 2007). This family of genes has been classified in three clades based, mainly, on their phylogenetic relations but also on conserved motifs in the $\mathrm{N}$ and $\mathrm{C}$ terminal parts of the protein. Within each family, the expression pattern of the gene members is different although they have retained some similar functions because some of them are able to complement the function of other members (Lin et al., 2013; Costanzo et al., 2014). For example WOX5 and WUS from Arabidopsis, who participate in maintenance of stem cells in root and shoot stem cells, respectively, are functionally equivalent and can complement each other's mutant (Mayer et al., 1998; Sarkar et al., 2007).

of interest, the clades reflect the gene ancestry; genes like WUS and WOX1-WOX7 are found in seed plants and belong to a derived clade; another intermediate clade consists of the genes WOX8, WOX9, WOX11, and WOX12 found in vascular plants including lycophytes, and the basal clade is comprised of WOX10, WOX13 and WOX14, which are found in vascular and nonvascular plants, including mosses and green algae (Lin et al., 2013; Lian et al., 2014). Genes from the intermediate clade have acquired protein motifs (up to seven) after the divergence from the ancestor that seems to have had only one motif, the homeodomain, as found in many members of the ancient clade (Lin et al., 2013; Lian et al., 2014). Curiously, all members of the modern clade contained only two motifs: the homeodomain and the so-called WUS box domain that is essential for repressor activity (Lin et al., 2013).

In many plant species, WOX1 and its orthologs are expressed in the adaxial-abaxial boundary of leaf primordia and many of these gene's mutants have severe leaf blade phenotypes; the most drastic is lam 1 of Nicotiana sylvestris that shows a bladeless leaf; this mutant has been used as a model system to study leaf morphogenesis. Lin and collaborators (2013) reported that lam 1 leaf mutant phenotype could be complemented with stenofilia (STF; WOX1 ortolog of Medicago truncatula), and with all the genes of the modern WOX clade from Arabidopsis using STF as the promoter. Moreover, they showed that proteins of the intermediate and ancient clades could not complement lam 1 leaf phenotypes, as they do not contain the WUS box or other repressor motif. The evolution of this gene family provides an example of cis (WUS and WOX5) and trans regulatory evolution (acquisition of different protein motifs). The shared target(s) of the WOX family members are still yet to be identified: these could shed light onto conserved molecular mechanisms involved in leaf morphogenesis.

\section{An Example in Maize}

Maize was domesticated from a Mexican teosinte species (Zea mays ssp. parviglumis or spp. mexicana) approximately 9,000 years ago. One of the main differences between maize and teosinte is the inflorescence architecture: in teosinte, several long branches with many tassels (male inflorescences) develop at the tip and many small dehiscent ears (female inflorescences) at the nodes, while maize has only one compound tassel and one or two large ears (indehiscent and compacted) (Wang et al., 1999; Studer et al., 2011). As an additional outcome of domestication, the grains contained in each ear expanded from 10 to 12 in teosinte to around 300 in maize. One of the main genes involved in such phenotypic differences is the transcription factor teosinte branched $1(t b 1)$, which is part of the TCP family (Cubas et al., 1999a).

During development, $t b 1$ acts as a repressor of the emergence of axillary branches; it is expressed in the axillary buds at different rates and it is more highly expressed in maize than in teosinte or other plant species like Arabidopsis (Finlayson, 2007), bamboo (Peng et al., 2007), barley (Ramsay et al., 2011), rice (Takeda et al., 2003), sorghum (Kebrom et al., 2006), and wheat (Lewis et al., 2008). The genetic basis of this phenotype in maize is related with the insertion of two transposable elements (called HOPSCOTCH and TOURIST) in the regulatory region of this gene. These insertions are missing in the regulatory region of teosinte's $t b 1$, and it has been shown that Hopscotch insertion functions as an enhancer of $t b 1$ expression in maize (Studer et al., 2011). Accordingly, changes in the levels of $t b 1$ expression underlie maize plant architecture evolution.

\section{Fitness Costs of Natural Regulatory Variation}

While most of the phenotypic diversity related to regulatory mutations reviewed here occurs in the wild (see Table 1), we practically know nothing about the stability of these variations in natural populations. However, it has been observed in greenhouse experiments that changes in the regulatory context of plants may alter fitness and have a dramatic impact on their ecological traits (Bossdorf et al., 2010).

Perhaps one of the most notable cases of an extreme floral homeosis fixed in natural populations is the inside-out flower of Lacandonia schismatica. The regularity of this phenotype was documented by Vergara-Silva et al. (2003), who analyzed more than 1000 L. schismatica inflorescences and discovered that only $2 \%$ of the flowers were unisexual, the rest were bisexual flowers with central stamens surrounded by peripheral carpels. As mentioned before, the unique floral arrangement of this Mexican species may be the result of either cis- or trans-regulator changes, although we do not rule out the possibility that both mechanisms may have had an important role during its evolution. 
Another example is the peloric variety of Linaria vulgaris, also discussed above, which displays actinomorphic flowers as a consequence of an epimutation in the CYCLOIDEA gene (Cubas et al., 1999a). Although it has been suggested that the Linaria epimutant may have a reduced fitness when compared with the wild-type flower, its populations have persisted for more than, 200 years (Hintz et al., 2006).

A plant known as shepherd's purse, Capsella bursa-pastoris, also exhibits stable populations in the wild of a floral homeotic variation, the decandric mutant. In decandric flowers, the four petals of C. bursa-pastoris are converted into functional stamens (Hintz et al., 2006). Although not intensively studied, it has been suggested that decandric mutants may have evolved as a result of an ectopic expression of a class $C$ gene in the second whorl. Despite the apetalous nature of these flowers, Hintz et al. (2006) confirm they have persisted in wild habitats as stable populations, perhaps by shifting their pollination syndrome, from bees to beetles, to which the amount of pollen produced by extra stamens might be more appealing.

A more recent analysis performed by Wang et al. (2011) also documented that some double flowered varieties, i.e., those where reproductive organs transform into extra petals, such as those present in natural populations of the Vinca minor flore pleno species, may persist in the wild for centuries, potentially establishing new evolutionary lineages.

\section{Understanding The Phenotypic Impacts of Altering Complex GRNS}

Contemporary biology is emphasizing the importance of a systems perspective to understanding how genetic and epigenetic alterations map onto phenotypical changes. In this study, we have reviewed some of the published examples of phenotypical alterations that have been related, mainly, to alterations of transcriptional regulatory components, but this does not mean that the associated phenotypes solely depend on the function of such individual factors in isolation.

In contrast, a systems approach considers that such phenotypes are the result of the concerted action of the identified components, in conjunction with other directly and indirectly related entities or factors (both genetic and nongenetic). Hence, the challenge becomes to understand the collective behavior that emerges from the interactions among identified regulators and other components, and not from the function of the individual components themselves. The latter must be considered as part of complex GRNs that we need to unravel and study as dynamical systems.

Multicellular development, that suggests cell differentiation and morphogenesis, is an example of an emergent behavior from collective and concerted action of many underlying components, among which transcriptional regulators seem to be key. Such dynamical processes as differentiation and proliferation within a temporal and spatial context self-organize without a central controller or choreographer. Cell differentiation, for example, has been successfully studied in terms of underlying regulatory networks (Kaufmann et al., 2009) and characterized by the stable multi-genic configurations to which such GRN converge. These configurations are referred to as attractors (Davila and ÁlvarezBuylla, 2015; Fig. 2).

The first GRN that was grounded on experimental data and formally analyzed was proposed for floral organ specification during early flower development (Mendoza and Álvarez-Buylla, 1998) and since then, the same approach has been used for other cases (Mendoza et al., 1999, 2000; Benítez et al., 2013; Azpeitia et al., 2013; Alvarez-Buylla et al., 2010c). Once such GRNs are established, uncovering the emergence and maintenance of the dynamical behavior from the concerted action of the molecular components being considered and their regulatory interactions, requires the use of mathematical/computational models (see Davila and Álvarez-Buylla, 2015, for a description of methods used and examples). Such methods enable mechanistic understanding of the role of particular genes or other types of molecular components in the context of the GRN to which they belong. For example, it is possible to simulate loss and gain of function mutations and assess the role of the altered components in the emergent multi-genic configurations that, in turn, alter cell fates. Thus a first approach to understanding why alterations in some genes are more important than others in underlying a particular phenotype (an altered cell-fate, in this case) is established.

For example, in Mendoza and Álvarez-Buylla (1998) and later in Espinosa-Soto et al. (2004) and further updatings of the floral organ specification GRN (Álvarez-Buylla et al., 2010c), a mechanistic GRN-based model was put forward to explain the $A B C$ model. The GRN model provided a mechanistic explanation of why the A, B, and C type genes are homeotic, and their mutations yield floral organ phenotypes in which one organ type is substituted by another one, as described above. Moreover, the same GRN model was able to explain the phenotypic impact in terms of altered cell fates for loss and gain of function mutations of all the components considered in the GRN model (see Espinosa-Soto et al., 2004).

In terms of such type of models, for example, we now understand that when a homeotic gene is turned off, the system switches from one attractor to another one (see Davila and Álvarez-Buylla, 2015, for a complete methodological description). An attractor is a stable multigenic configuration that characterizes a cell type. Hence, for example, when AP3, a petal and stamen specific transcriptional regulator is turned off and the B function is lost, petals and stamens differentiate into sepals and carpels (Coen and Meyerowitz, 1991). This is so because this gene occupies a position within a positive regulatory loop of the GRN and functions in a "switch-like" manner, in such a way that its activation makes the system follow a particular trajectory until reaching a stable point or attractor (that of petals and stamens), and when it is turned off, it makes the system follow a different trajectory and reach another attractor (or cell-fate; that of sepals and carpels). Such contrasting emergent behaviors depend on the way the components are interconnected within the GRN module to which they belong (see Espinosa-Soto et al., 2004, for further details), and not on their individual function.

GRN models only consider the interactions that restrict the system to particular multi-genic configurations that are characteristic of particular cell-fates. Physical and chemical fields, as well as cell proliferation dynamics, cell-cell communication, stochastic fluctuations, among others, have to be considered to understand how specific genetic and epigenetic alterations alter morphogenetic patterns during development and underlie phenotypical evolution (Álvarez-Buylla et al., 2007, 2008; Barrio et al., 2010; Azpeitia et al., 2013).

The present review identifies several transcriptional regulatory nodes and alterations that seem to be key in underlying phenotypical changes. Thus the challenge now becomes to put together 
new GRN modules in which these nodes participate (see de Almeida et al., 2014, for an example of a critical node within the polarity GRN module) and, based on their dynamic analyses, provide a mechanistic explanation for their role in development and phenotypic shifts during plant evolution, as the one that was achieved for the ABC mutants (Espinosa-Soto et al., 2004 and references that followed), which we have summarized above.

\section{Technological Approaches To Discover GRN Components}

A point of great concern for many evolutionary biologists has been the restrictions on experimental approaches that can be applied to unravel the functional effects of particular genes, as well as the lack of reference genomes/transcriptomes in nonmodel species; both approaches have been instrumental in the identification of interactions amongst genes embedded in a GRN. Nowadays, recent advances using Next Generation Sequencing (NGS) technologies and bioinformatics pipelines are generating a large amount of sequence information that can help study various aspects of genome evolution and architecture, as well as the interconnection among genes that are part of a GRN. NGS can be applied to DNA genome sequencing, transcriptomics (RNA-Seq), detection of single nucleotide polymorphisms (SNPs), chromatin immunoprecipitation (ChIP) or ChIP-chip, identification of sRNA and epigenome characterization.

Specifically, the construction of transcriptome libraries derived from organ, tissue, structure, treatment-specific cDNA assemblies can allow for the characterization of the transcriptional profile of an organism during different developmental or physiological states. This enables the isolation of genes that are likely involved in a particular trait, as well as the isolation of candidate genes that have presumably conserved functions, given what has been thoroughly characterized in model systems. Furthermore, the study of their particular expression/repression patterns during specific times of development of distinct organ types, such as the floral organ whorls described above, can be used as a proxy to infer logical rules for all genes of interest across all tissue types assayed. Such inference can feed into formal biomathematical models of gene interaction such as the GRNs described.

Whole-genome and tandem duplications are ubiquitous phenomena in angiosperm evolution and have given rise to the presence of paralogs in many plant lineages; the role of such duplicates in modifying the dynamics and interactions among genes that are part of underlying GRNs involved in different aspects of plant development could be formally and systematically tested, as has already been suggested for the case of the Petunia B-class gene paralogs by Espinosa-Soto et al. (2004; see Fig. 2).

\section{Concluding Remarks and Perspectives}

Our brief overview of cases where the gene(s) that affect a particular trait have been characterized and the molecular processes that yield contrasting phenotypes have been investigated, suggests that in plants as well as in animals, cis-regulatory evolution is an important driver in the diversification of form (Table 1). In plants, changes in cis-regulatory sequences in orthologous genes explain variations in phenotype between closely related species for phenomena such as anthocyanin synthesis (Ipomea, Phlox,
Mimulus, Petunia, Lycopersicon, apple, oranges, and grapes); repression of secondary branching structures (maize), leaf development (Brassicaceae family and Capsella), and vernalization requirements by ecotypes of $A$. thaliana. Gene duplication seems to also facilitate mutations in the regulatory sequence of one or both paralogs, which have been correlated with differential gene expression, as exemplified by the ICS in Physalis and relatives, as well as with the expression of genes involved in pigmentation in Petunia species. Nonetheless, gene duplication has also led to gene subfunctionalization by means of trans changes in the cDNAs of developmentally important genes, as has been documented for flower development in Papaver, Solanum, and Antirrhinum, while the role of epigenetic regulation of plant development and its capacity to generate contrasting phenotypes based on changes in floral symmetry, sexual organ development or phenotypic plasticity have been documented for Linaria, melon and Arabidopsis thaliana and Laguncularia racemosa, respectively.

The examples integrated here point to some key components of regulatory modules underlying the emergence of phenotypic shifts in plant vegetative and reproductive structures as a result of alterations in epigenetic regulation, mutations in regulatory regions of implicated genes or in the coding sequences of transcription factors themselves. Arguing about the relative importance of how different types of molecular alterations contribute to phenotypic evolution is a sterile debate (Hilscher et al., 2009). Rather, we need mechanistic and predictive frameworks, such as those being proposed by GRN and epigenetic landscape models, which enable us to understand why the alterations in the expression of particular components are more critical for phenotypic change than others.

Each one of the cases reviewed here opens the possibility to integrate or further explore the components of the relevant regulatory module in which the studied genes participate. Formal GRN models for these modules will then be useful to predict additional phenotypes and provide mechanistic and dynamic explanations to such phenotypic variation (Álvarez-Buylla et al., 2007, 2010c). This approach will yield a repertoire of regulatory modules in the search for general principles concerning the mechanisms by which phenotypic variation arises from changes at the molecular level.

It is noteworthy that most of the cases in which a particular and relatively simple molecular alteration has been associated with a clear phenotypic change correspond to genes that code for transcription factors. These are probably the nodes with more interactions within their respective GRN. Hence, it is likely that alterations in the expression patterns of these genes are sufficient to cause an alteration in the GRN stable states, or in the resulting phenotype. More detailed explanations will benefit from further elaborations of developmental models grounded on experimental data for particular functional or morphological modules.

\section{Acknowledgments}

We are most grateful to Diana Romo for her help with logistical support. Grant sponsor: CONACyT 180098, 180380, 167705, 152649 and PAPIIT UNAM IN203214-3, IN203113-3, IN2038143. BFU2012-34821 (MINECO) to C.G. and an institutional grant from Fundación Ramón Aceres to CBMSO. E.R.A.-B. was supported by the Miller Institute for Basic Research in Science, University of California, Berkeley, California. A.G.A. was supported by a 
sabatical fellowship by CONACyT and by PASPA, UNAM. A.P.N. was supported by a Postdoctoral Fellowship by UC-MexusCONACYT. A.P.N. is grateful for the support provided by C.D. Specht, A.M.R. Almeida, and R. Yockteng during her postdoctoral research. We apologize to those whose work we have inadvertently overlooked in this review.

\section{References}

Airoldi CA, Bergonzi S, Davies B. 2010. Single amino acid change alters the ability to specify male or female organ identity. Proc Natl Acad Sci U S A 107:18898-18902.

Airoldi CA, Davies B. 2012. Gene duplication and the evolution of plant MADS-box transcription factors. J Genet Genom 39:157165.

Alonso CR, Wilkins AS. 2005. The molecular elements that underlie developmental evolution. Nat Rev Genet 6:709-715.

Álvarez-Buylla E, Pelaz S, Liljegren SJ, Gold SE, Burgeff C, Ditta GS, Ribas de Pouplana L, Martínez-Castilla L, Yanofsky MF. 2000. An ancestral MADS-box gene duplication occurred before the divergence of plants and animals. Proc Natl Acad Sci U S A 97:5328-5333.

Álvarez-Buylla ER, Benítez M, Espinosa-Soto C. 2007. Phenotypic evolution is restrained by complex developmental processes. HFSP J 1:99-103.

Álvarez-Buylla ER, Chaos Á, Aldana M, Benítez M Cortes-Poza Y, Espinosa-Soto C, Hartasánchez DA, Beau Lotto R, Malkin D, Escalera Santos GJ, Padilla-Longoria P. 2008. Floral morphogenesis: stochastic explorations of a gene network epigenetic landscape. PLoS One 3:e3626.

Álvarez-Buylla ER, Benítez M, Corvera-Poiré A, Chaos Cador A, de Folter S, Gamboa de Buen A, Garay-Arroyo A, García-Ponce B, Jaimes-Miranda F, Pérez-Ruiz RV, Piñeyro-Nelson A, SánchezCorrales YE. 2010a. Flower development. Arabidopsis Book 8: e0127.

Álvarez-Buylla ER, Ambrose BA, Flores-Sandoval E, Englund M, Garay-Arroyo A, García-Ponce B, de la Torre-Bárcena E, Espinosa-Matías S, Martínez E, Piñeyro-Nelson A, Engström P, Meyerowitz EM. 2010b. B-function expression in the flower center underlies the homeotic phenotype of Lacandonia schismatica (Triuridaceae). Plant Cell 22:3543-3559.

Álvarez-Buylla ER, Azpeitia E, Barrio R, Benítez M, PadillaLongoria P. 2010c. From ABC genes to regulatory networks, epigenetic landscapes and flower morphogenesis: making biological sense of theoretical approaches. Semin Cell Dev Biol 21: 108-117.

Arbeitman MN, Furlong EE, Imam F, Johnson E, Null BH, Baker BS, Krasnow MA, Scott MP, Davis RW, White KP. 2002. Gene expression during the life cycle of Drosophila melanogaster. Science 297:2270-2275.

Azpeitia E, Weinstein N, Benítez M, Mendoza L, Álvarez-Buylla ER. 2013. Finding missing interactions of the Arabidopsis thaliana root stem cell niche gene regulatory network. Front Plant Sci 4: 110.

Arnaud N, Lawrenson T, Ostergaard L, Sablowski R. 2011. The same regulatory point mutation changed seed-dispersal structures in evolution and domestication. Curr Biol 21:1-5.

Barrio RA, Hernández-Machado A, Varea C, Romero-Arias JR, Álvarez-Buylla ER. 2010. Flower development s an interplay between dynamical physical fields and genetic networks. PLoS One 5:e13523.

Barrio RA, Romero-Arias JR, Noguez MA, Azpeitia E, OrtizGutiérrez E, Hernández-Hernández V, Cortes-Poza Y, ÁlvarezBuylla ER. 2013. Cell patterns emerge from coupled chemical and physical fields with cell proliferation dynamics: the Arabidopsis thaliana root as a study system. PLoS Comput Biol 9: e1003026.

Bartee L, Malagnac F, Bender J. 2001. Arabidopsis cmt3 chromomethylase mutations block non-CG methylation and silencing of an endogenous gene. Genes Dev 15:1753-1758.

Benítez M, Azpeitia E, Alvarez-Buylla ER. 2013. Dynamic models of epidermal patterning as an approach to plant eco-evo-devo. Curr Opin Plant Biol 16:11-18.
Bernacchi D, Tanksley SD. 1997. An interspecific backcross of Lycopersicon esculentum $x \mathrm{~L}$. hirsutum: linkage analysis and a QTL study of sexual compatibility factors and floral traits. Genetics 147:861-877.

Beckerman M. 2005. Molecular and cellular signaling. New York: Springer Science.

Berger SL, Kouzarides T, Shiekhattar R, Shilatifard A. 2009. An operational definition of epigenetics. Genes Dev 23:781-783.

Bharathan G, Goliber TE, Moore C, Kessler S, Pham T, Sinha NR. 2002. Homologies in leaf form inferred from KNOXI gene expression during development. Science 296:1858-1860.

Borneman AR, Gianoulis TA, Zhang ZD, Yu H, Rozowsky J, Seringhaus MR, Wang LY, Gerstein M, Snyder M. 2007. Divergence of trancription factor binding sites across related yeast species. Science 317:815-819.

Bossdorf O, Arcurri D, Richards CL, Pigliucci M. 2010. Experimental alteration of DNA methylation affects the phenotypic plasticity of ecologically relevant traits in Arabidopsis thaliana. Evol Ecol 24:541-553.

Bowman JL, Smyth DR, Meyerowitz EM. 1989. Genes directing flower development in Arabidopsis. Plant Cell 1:37-52.

Bowman JL, Smyth DR, Meyerowitz EM. 1991. Genetic interactions among floral homeotic genes in Arabidopsis. Development 112:1-20.

Brakefield PM. 2006. Evo-devo and constraints on selection. Trends Ecol Evol 21:362-368.

Bradley RK, Li XY, Trapnell C, Davidson S, Pachter L, Chu HC, Tonkin LA, Biggin MD, Eisen MB. 2010. Binding site turnover produces pervasive quantitative changes in transcription factor binding between closely related Drosophila species. PLoS Biol 8: e1000343.

Bradshaw HD, Wilbert SM, Otto KG, Schemske DW. 1995. Genetic mapping of floral traits associated with reproductive isolation in monkeyflowers (Mimulus). Nature 376:762-765.

Bräutigam K, Vining KJ, Lafon-Placette C, Fossdal CG, Mirouze M, Gutiérrez Marcos J, Fluch S, Fernández Fraga M, Guevara MA, Abarca D, Johnsen $\varnothing$, Maury S, Strauss SH, Campbell MM, Rohde A, Díaz-Sala C, Cervera M-T. 2013. Epigenetic regulation of adaptive responses of forest tree species to the environment. Ecol Evol 3:399-415.

Britten RJ, Davidson EH. 1969. Gene regulation for higher cells: a theory. Science 165:349-357.

Britten RJ, Davidson EH. 1971. Repetititve and non-repetititve DNA sequences and a speculation on the origins of evolutionary novelty. Q Rev Biol 46:111-138.

Butelli E, Licciardello C, Zhang Y, Liu J, Mackay S, Bailey P, Reforgiato-Recupero G, Martin C. 2012. Retrotransposons control fruit-specific, cold-dependent accumulation of anthocyanins in blood oranges. Plant Cell 24:1242-1255.

Cao X, Jacobsen SE. 2002. Role of the Arabidopsis DRM methyltransferases in de novo DNA methylation and gene silencing. Curr Biol 12:1138-1144.

Carroll SB. 2005. Evolution at two levels: on genes and form. PloS Biology 3:e245.

Carroll SB. 2008. Evo-devo and an expanding evolutionary synthesis: a genetic theory of morphological evolution. Cell 134:25-36.

Chae E, Tan QK, Hill TA, Irish VF. 2008. An Arabidopsis F-box protein acts as a transcriptional co-factor to regulate floral development. Development 135:1235-1245.

Chaudhary B, Flagel L, Stupar RM, Udall JA, Verma N, Springer NM, Wendel JF. 2009. Reciprocal silencing, transcriptional bias and functional divergence of homeologs in polyploid cotton (Gossypium). Genetics 182:503-517.

Chen JJ, Janssen BJ, Williams A, Sinha N. 1997. A gene fusion at a homeobox locus: alterations in leaf shape and implications for morphological evolution. Plant Cell 9:1289-1304.

Chen KY, Cong B, Wing R, Vrebalov J, Tanksley SD. 2007. Changes in regulation of a transcription factor lead to autogamy in cultivated tomatoes. Science 318:643-645.

Coen E, Meyerowitz EM. 1991. The war of the whorls: genetic interactions controlling flower development. Nature 353:31-37.

Cohen A, Mayfield SP. 1997. Translational regulation of gene expression in plants. Curr Opin Biotech 8:189-194.

Costanzo E, Trehin C, Vandenbussche M. 2014. The role of WOX genes in flower development. Ann Bot 114:1545-1553. 
Cubas P, Vincent C, Coen E. 1999a. An epigenetic mutation responsible for natural variation in floral symmetry. Nature 401: 157-161.

Cubas P, Lauter N, Doebley J, Coen E. 1999b. The TCP domain: a motif found in proteins regulating plant growth and development. Plant J 18:215-222.

Davidson EH, Erwin DH. 2006. Gene regulatory networks and the evolution of animal body plans. Science $311: 796-800$.

Davila-Velderrain J, Servin-Marquez A, Alvarez-Buylla ER. 2014. Molecular evolution constraints in the floral organ specification gene regulatory network module across 18 angiosperm genomes. Mol Biol Evol 31:560-573.

Davila-Velderrain J, Álvarez-Buylla ER. 2015. Bridging the genotype and the phenotype: towards an epigenetic landscape approach to evolutionary systems biology. BioRxiv 1-15.

de Almeida AM, Yockteng R, Schnable R, Álvarez-Buylla ER, Freeling M, Specht CD. 2014. Co-option of the polarity gene network shapes filament morphology in angiosperms. Sci Rep 29: 6194.

Des Marais DL, Rausher MD. 2010. Parallel evolution at multiple levels in the origin of hummingbird pollinated flowers in Ipomoea. Evolution 64:2044-2054.

de Martino G, Pan I, Emmanuel E, Levy A, Irish VF. 2006. Functional analyses of two tomato APETALA3 genes demonstrate diversification in their roles in regulating floral development. Plant Cell 18:1833-1845.

Desvoyes B, Fernández-Marcos M, Sequeira-Mendes J, Otero S, Vergara Z, Gutierrez C. 2014. Looking at plant cell cycle from the chromatin window. Front Plant Sci 5:369.

Drea S, Hileman LC, de Martino G, Irish VF. 2007. Functional analyses of genetic pathways controlling petal specification in poppy. Development 134:4157-4166.

Dudareva N, Raguso RA, Wang J, Ross JR, Pichersky E. 1998. Floral scent production in Clarkia breweri. Plant Physiol 116:599604.

Durbin ML, Lundy KE, Morrell PL, Torres-Martinez CL, Clegg MT. 2003. Genes that determine flower color: the role of regulatory changes in the evolution of phenotypic adaptations. Mol Phylogenet Evol 29:507-518.

Egea-Cortines M, Saedler H, Sommer H. 1999. Ternary complex formation between the MADS-box proteins SQUAMOSA, DEFICIENS and GLOBOSA is involved in the control of floral architecture in Antirrhinum majus. EMBO J 18:5370-5379.

Emerson JJ, Li WH. 2010. The genetic basis of evolutionary change in gene expression levels. Philos Trans R Soc Lond B Biol Sci 365:2581-2590.

Espinosa-Soto C, Padilla-Longoria P, Alvarez-Buylla ER. 2004. A gene regulatory network model for cell-fate determination during Arabidopsis thaliana flower development that is robust and recovers experimental gene expression profiles. Plant Cell 16: 2923-2939.

Espley RV, Hellens RP, Putterill J, Stevenson DE, Kutty-Amma S, Allan AC. 2007. Red colouration in apple fruit is due to the activity of the MYB transcription factor, MdMYB10. Plant J 49:414427.

Espley RV, Brendolise C, Chagné D, Kutty-Amma S, Green S, Volz R, Putterill J, Schouten HJ, Gardiner SE, Hellens RP, Allan AC. 2009. Multiple repeats of a promoter segment causes transcription factor autoregulation in red apples. Plant Cell 21:168-183.

Finlayson SA. 2007. Arabidopsis teosinte branched1-like 1 regulates axillary bud outgrowth and is homologous to monocot teosinte branched1. Plant Cell Physiol 48:667-677.

Fordyce JA. 2006. The evolutionary consequences of ecological interactions mediated through phenotypic plasticity. J Exp Biol 209:2377-2383

Fukushima K, Hasebe M. 2014. Adaxial-abaxial polarity: the developmental basis of leaf shape diversity. Genesis 52:1-18.

Fulton TM, Beck-Bunn T, Emmatty D, Eshed Y, Lopez J, Petiard V, Uhlig J, Zamir D, Tanksley SD. 1997. QTL analysis of an advanced backcross of Lycopersicon peruvianum to the cultivated tomato and comparisons with QTLs found in other wild species. Theor Appl Genet 95:881-894.

Furner IJ, Matzke M. 2011. Methylation and demethylation of the Arabidopsis genome. Curr Opin Plant Biol 14:137-141.
Geuten K, Irish V. 2010. Hidden variability of floral homeotic B genes in Solanaceae provides a molecular basis for the evolution of novel functions. Plant Cell 22:2562-2578.

Ghalambor CK, McKay JK, Carroll SP, Reznick DN. 2007. Adaptive versus non-adaptive phenotypic plasticity and the potential for contemporary adaptation in new environments. Funct Ecol 21: 394-407.

Gilbert SF, Epel D. 2009. Ecological developmental biology. Integrating epigenetics, medicine and evolution. Sunderland, MA: Sinauer Associates, Inc.

Gilbert SF, McDonald E, Boyle N, Buttino N, Gyi L, Mai M, Prakash N, Robinson J. 2010. Symbiosis as a source of selectable epigenetic variation: taking the heat from the big guy. Philos Trans $\mathrm{R}$ Soc Lond B Biol Sci 365:671-678.

Gompel N, Prud'homme B, Wittkopp PJ, Kassner VA, Carroll SB. 2005. Chance caught on the wing: cis-regulatory evolution and the origin of pigment patterns in Drosophila. Nature 433:481487.

Goode DK, Callaway HA, Cerda GA, Lewis KE, Elgar G. 2011. Minor change, major difference: divergent functions of highly conserved cis-regulatory elements subsequent to whole genome duplication events. Development 138:879-884.

Gong W, Shen YP, Ma LG, Pan Y, Du YL, Wang DH, Yang JY, Hu LD, Liu XF, Dong CX, Ma L, Chen YH, Yang XY, Gao Y, Zhu D, Tan X, Mu JY, Zhang DB, Liu DL, Dinesh-Kumar SP, Li Y, Wang XP, Gu HY, Qu LJ, Bai SN, Lu YT, Li JY, Zhao JD, Zuo J, Huang H, Deng XW, Zhu YX. 2004. Genome-wide ORFeome cloning and analysis of Arabidopsis transcription factor genes. Plant Physiol 135:773-782.

Goto K, Meyerowitz EM. 1994. Function and regulation of the Arabidopsis floral homeotic gene PISTILLATA. Genes Dev 8:15481560.

Gramzow L, Theissen G. 2010. A hitchhiker's guide to the MADS world of plants. Genome Biol 11:214.

Gramzow L, Theißen G. 2013. Phylogenomics of MADS-Box genes in plants - two opposing life styles in one gene family. Biology (Basel) 12:1150-1164.

Grimanelli D, Roudier F. 2013. Epigenetics and development in plants: green light to convergent innovations. Curr Top Dev Biol 104:189-222.

Gruber JD, Vogel K, Kalay G, Wittkopp PJ. 2012. Contrasting properties of gene-specific regulatory, coding, and copy number mutations in Saccharomyces cerevisiae: frequency, effects, and dominance. PLoS Genet 8:e1002497.

Haecker A, Gross-Hardt R, Geiges B, Sarkar A, Breuninger H, Herrmann M, Laux T. 2004. Expression dynamics of WOX genes mark cell fate decisions during early embryonic patterning in Arabidopsis thaliana. Development 131:657-668.

Hareven D, Gutfinger T, Parnis A, Eshed Y, Lifschitz E. 1996. The making of a compound leaf: genetic manipulation of leaf architecture in tomato. Cell 84:735-744.

Hay A, Tsiantis M. 2006. The genetic basis for differences in leaf form between Arabidopsis thaliana and its wild relative Cardamine hirsuta. Nat Genet 38:942-947.

Hay A, Tsiantis M. 2010. KNOX genes: versatile regulators of plant development and diversity. Development 137:3153-3165.

He CY, Saedler H. 2005. Heterotopic expression of MPF2 is the key to the evolution of the chinese lantern of Physalis, a morphological novelty in Solanaceae. Proc Natl Acad Sci U S A 102: 5779-5784.

He CY, Saedler H. 2007. Hormonal control of the inflated calyx syndrome, a morphological novelty, in Physalis. Plant J 49:935946.

Hernández-Hernández T, Martínez-Castilla LP, Alvarez-Buylla ER. 2007. Functional diversification of B MADS-box homeotic regulators of flower development: adaptive evolution in protein-protein interaction domains after major gene duplication events. Mol Biol Evol 24:465-481.

Herrera CM, Bazaga P. 2010. Epigenetic differentiation and relationship to adaptive genetic divergence in discrete populations of the violet Viola cazorlensis. New Phytol 187:867-876.

Hilscher J, Schlötterer C, Hauser MT. 2009. A single aminoacid replacement in ETC2 shapes trichome patterning in natural Arabidopsis populations. Curr Biol 19:1747-1751. 
Hintz M, Bartholmes C, Nutt P, Ziermann J, Hameister S, Neuffer B, Theissen G. 2006. Catching a 'hopeful monster': sheperd's purse (Capsella bursa-pastoris) as a model system to study the evolution of flower development. J Exp Bot 57:3531-3542.

Hirochika H, Okamoto H, Kakutani T. 2000. Silencing of retrotransposons in Arabidopsis and reactivation by the ddm1 mutation. Plant Cell 12:357-369.

Hoballah ME, Gubitz T, Stuurman J, Broger L, Barone M, Mandel T, Dell'Olivo A, Arnold M, Kuhlemeier C. 2007. Single-gene mediated shift in pollinator attraction in Petunia. Plant Cell 19:779790.

Hoekstra HE, Coyne JA. 2007. The locus of evolution: evo devo and the genetics of adaptation. Evolution 61:995-1016.

Holton TA, Cornish EC. 1995. Genetics and biochemistry of anthocyanin biosynthesis. Plant Cell 7:1071-1083.

Honma T, Goto K. 2001. Complexes of MADS-box proteins are sufficient to convert leaves into floral organs. Nature 409:525529.

Hopkins R, Rausher MD. 2011. Identification of two genes causing reinforcement in the Texas wildflower Phlox drummondii. Nature 469:411-414.

Hopkins R, Rausher MD. 2012. Pollinator-mediated selection on flower color allele drives reinforcement. Science 335:1090-1092.

Hopkins R. 2013. Reinforcement in plants. New Phytol 197:10951103.

Irish V. 2009. Evolution of petal identity. J Exp Bot 60:2517-2527.

lyer VR, Horak CE, Scafe CS, Botstein D, Snyder M, Brown PO. 2001. Genomic binding sites of the yeast cell-cycle transcription factors SBF and MBF. Nature 409:533-538.

Jacob F. 1977. Evolution and tinkering. Science 196:1161-1166.

Jacob F, Monod J. 1961. Genetic regulatory mechanisms in the synthesis of proteins. J Mol Biol 3:318-356.

Jack T, Brockman LL, Meyerowitz EM. 1992. The homeotic gene APETALA3 of Arabidopsis thaliana encodes a MADS box and is expressed in petals and stamens. Cell 68:683-697.

Jeong S, Rokas A, Carroll SB. 2006. Regulation of body pigmentation by the abdominal-b hox protein and its gain and loss in Drosophila evolution. Cell 125:1387-1399.

Kankel MW, Ramsey DE, Stokes TL, Flowers SK, Haag JR, Jeddeloh JA, Riddle NC, Verbsky ML, Richards EJ. 2003. Arabidopsis MET1 cytosine methyltransferase mutants. Genetics 163: $1109-1122$.

Kanno A, Nakada M, Akita Y, Hirai M. 2007. Class B gene expression and the modified $A B C$ model in nongrass monocots. Sci World J 19:268-279.

Kasowski M, Grubert F, Heffelfinger C, Hariharan M, Asabere A Waszak SM, Habegger L, Rozowsky J, Shi M, Urban AE, Hong MY, Karczewski KJ, Huber W, Weissman SM, Gerstein MB, Korbel JO, Snyder M. 2010. Variation in transcription factor binding among humans. Science 328:232-235.

Kauffman S. 1969. Homeostasis and differentiation in random genetic control networks. Nature 224:177-178.

Kaufmann K, Muiño JM, Jauregui R, Airoldi CA, Smaczniak C, Krajewski P, Angenent GC. 2009. Target genes of the MADS transcription factor SEPALLATA3: integration of developmental and hormonal pathways in the Arabidopsis flower. PLoS Biol 7:e1000090.

Kaufmann K, Pajoro A, Angenent GC. 2010. Regulation of transcription in plants: mechanisms controlling developmental switches. Nat Rev Genet 11:830-842.

Kayo T, Allison DB, Weindruch R, Prolla TA. 2001. Influences of aging and caloric restriction on the transcriptional profile of skeletal muscle from rhesus monkeys. Proc Natl Acad Sci U S A 98: 5093-5098.

Kebrom TH, Burson BL, Finlayson SA. 2006. Phytochrome B represses Teosinte Branched1 expression and induces sorghum axillary bud outgrowth in response to light signals. Plant Physiol 140:1109-1117.

Khan MR, Hu JY, Riss S, He CY, Saedler H. 2009. MPF2-like MADS-box genes control the inflated calyz syndrome in Withania (Solanaceae): roles of Darwinian's selection. Mol Biol Evol 26: 2463-2473.

Khan MR, Hu J, Ali GM. 2012. Reciprocal loss of CArG-boxes and Auxin Response Elements drives expression divergence of
MPF2-like MADS-Box genes controlling calyx inflation. PLoS One 7:e42781.

Kim S, Yoo MJ, Albert VA, Farris JS, Soltis PS, Soltis DE. 2004. Phylogeny and diversification of B-function MADS-box genes in angiosperms: evolutionary and functional implications of a 260million-year-old duplication. Am J Bot 91:2102-2118.

King MC, Wilson AC. 1975. Evolution at two levels in humans and chimpanzees. Science 188:107-116.

Klahre U, Gurba A, Hermann K, Saxenhofer M, Bossolini E, Guerin PM, Kuhlemeier C. 2011. Pollinator choice in Petunia depends on two major genetic loci for floral scent production. Curr Biol 21:730-739.

Knapp S. 2002. Tobacco to tomatoes: a phylogenetic perspective on fruit diversity in the Solanaceae. J Exp Bot 53:2001-2022.

Kobayashi S, Ishimaru M, Hiraoka K, Honda C. 2002. Myb-related genes of the Kyoho grape (Vitis labruscana) regulate anthocyanin biosynthesis. Planta 215:924-933.

Kobayashi S, Goto-Yamamoto N, Hirochika N. 2004. Retrotransposon-induced mutations in grape skin color. Science 304:982.

Kohler C, Grossniklaus U. 2005. Seed development and genomic imprinting in plants. Prog Mol Subcell Biol 38:237-262.

Krizek BA, Meyerowitz EM. 1996. Mapping the protein regions responsible for the functional specificities of the Arabidopsis MADS domain organ-identity proteins. Proc Natl Acad Sci U S A 93:4063-4070.

Latchman DS. 2008. Eukaryotic Transcription Factors. Academic Press. London, UK.

Law JA, Jacobsen SE. 2010. Establishing, maintaining and modifying DNA methylation patterns in plants and animals. Nat Rev Genet 11:204-220.

Lemon B, Tjian R. 2000. Orchestrated response: a symphony of transcription factors for gene control. Genes Dev 14:2551-2569.

Levin DA. 1985. Reproductive character displacement in Phlox. Evolution 39:1275-1281.

Lewis JM, Mackintosh CA, Shin S, Gilding E, Kravchenko S, Baldridge G, Zeyen R, Muehlbauer GJ. 2008. Overexpression of the maize Teosinte Branched1 gene in wheat suppresses tiller development. Plant Cell Rep 27:1217-1225.

Lin H, Niu L, McHale NA, Ohme-Takagi M, Mysore KS, Tadege M. 2013. Evolutionarily conserved repressive activity of WOX proteins mediates leaf blade outgrowth and floral organ development in plants. Proc Natl Acad Sci U S A 110:366-371.

Lian G, Ding Z, Wang Q, Zhang D, Xu J. 2014. Origins and evolution of WUSCHEL-related homeobox protein family in plant kingdom. Sci World J 2014:534140.

Lindroth AM, Cao X, Jackson JP, Zilberman D, McCallum CM, Henikoff S, Jacobsen SE. 2001. Requirement of CHROMOMETHYLASE3 for maintenance of CPXpG methylation. Science 292: 2077-2080.

Lippman Z, Gendrel AV, Black M, Vaughn MW, Dedhia N, McCombie WR, Lavine K, Mittal V, May B, Kasschau KD, Carrington JC, Doerge RW, Colot V, Martienssen R. 2004. Role of transposable elements in heterochromatin and epigenetic control. Nature 430:471-476.

Lira-Medeiros CF, Parisod C, Avancini Fernandes R, Souza Mata C, Aires Cardoso M, Ferreira PCG. 2010. Epigenetic variation in mangrove plants occurring in contrasting natural environment. PLoS One 5:e10326.

Love AC, Raff RA. 2003. Knowing your ancestors: themes in the history of evo-devo. Evol Dev 5:327-330.

Luo D, Carpenter R, Vincent C, Copsey L, Coen E. 1996. Origin of floral asymmetry in Antirrhinum. Nature 383:794-799.

Maizel A, Busch MA, Tanahashi T, Perkovic J, Kato M, Hasebe M, Weigel D. 2005. The floral regulator LEAFY evolves by substitutions in the DNA binding domain. Science 308:260-263.

Marsch-Martínez N, Zúñiga-Mayo VM, Herrera-Ubaldo $H$, Ouwerkerk PB, Pablo-Villa J, Lozano-Sotomayor P, Greco R, Ballester P, Balanzá V, Kuijt SJ, Meijer AH, Pereira A, Ferrándiz C, de Folter S. 2014. The NTT transcription factor promotes replum development in Arabidopsis fruits. Plant $\mathrm{J}$ 80:69-81.

Martin A, Troadec C, Boualem A, Rajab M, Fernandez R, Morin H, Pitrat M, Dogimont C, Bendahmane A. 2009. A transposoninduced epigenetic change leads to sex determination in melon. Nature 461:1135-1138. 
Martínez E, Ramos CH. 1989. Lacandoniaceae (Triuridales), a new family of Mexican plants. Ann Mo Bot Gard 76:128-135.

Martínez-Castilla LP, Álvarez-Buylla ER. 2003. Adaptive evolution in the Arabidopsis MADS-box gene family inferred from its complete resolved phylogeny. Proc Nat Acad Sci U S A 100:13407-13412.

Matzke MA, Mosher RA. 2014. RNA-directed DNA methylation: an epigenetic pathway of increasing complexity. Nat Rev Genet 15: 394-408.

Mayer KF, Schoof H, Haecker A, Lenhard M, Jürgens G, Laux T. 1998. Role of WUSCHEL in regulating stem cell fate in the Arabidopsis shoot meristem. Cell 95:805-815.

Meiklejohn CD, Coolon JD, Hartl DL, Wittkopp PJ. 2014. The roles of cis- and trans- regulation in the evolution of regulatory incompatibilities and sexually dimorphic gene expression. Genome Res 24:84-95.

Melzer R, Theissen G. 2011. MADS and more: transcription factors that shape the plant. Methods Mol Biol 754:3-18.

Melo A, Alves M. 2012. The discovery of Lacandonia (Triuridaceae) in Brazil. Phytotaxa 40:21-25.

Mendoza L, Álvarez-Buylla ER. 1998. Dynamics of the genetic regulatory network for Arabidopsis thaliana flower morphogenesis. J Theor Biol 193:307-319.

Mendoza L, Thieffry D, Álvarez-Buylla ER. 1999. Genetic control of flower morphogenesis in Arabidopsis thaliana: a logical analysis. Bioinformatics 15:593-606.

Michaels SD, Amasino RM. 1999. FLOWERING LOCUS C encodes a novel MADS domain protein that acts as a repressor of flowering. Plant Cell 11:949-956.

Michaels SD, He Y, Scortecci KC, Amasino RM. 2003. Attenuation of FLOWERING LOCUS C activity as a mechanism for the evolution of summer-annual flowering behavior in Arabidopsis. Proc Natl Acad Sci U S A 100:10102-10107.

Mody M, Cao Y, Cui Z, Tay KY, Shyong A, Shimizu E, Pham K, Schultz P, Welsh D, Tsien JZ. 2001. Genome wide gene expression profiles of the developing mouse hippocampus. Proc Natl Acad Sci U S A 98:8862-8867.

Mondragón-Palomino M, Theissen G. 2009. Why are orchid flowers so diverse? Reduction of evolutionary constraints by paralogues of class B floral homeotic genes. Ann Bot 104:583-594.

Mondragón-Palomino M, Hiese L, Härter A, Koch MA, Theissen G. 2009. Positive selection and ancient duplications in the evolution of class B floral homeotic genes of orchids and grasses. BMC Evol Biol 21:81.

Moyroud E, Reymond MCA, Hamès C, Parcy F, Scutt CP. 2009 The analysis of entire gene promoters by surface plasmon resonance. The Plant Journal 59:851-858.

Moyroud E, Kusters E, Monniaux M, Koes R, Parcy F. 2010. LEAFY blossoms. Trends Plant Sci 15:346-352.

Müller GB. 2007. Evo-devo: extending the evolutionary synthesis. Nat Rev Genet 8:943-949.

Nackley AG, Shabalina SA, Tchivileva IE, Satterfield K, Korchynskyi O, Makarov SS, Maixner W, Diatchenko L. 2006. Human catechol-O-methyltransferase haplotypes modulate protein expression by altering mRNA secondary structure. Science 314 : 1930-1933.

Neznanov N, Umezawa A and Oshima RG. 1997. A regulatory element within a coding exon modulates keratin 18 gene expression in transgenic mice. J Biol Chem 272:27549-27557.

Odom DT, Dowell RD, Jacobsen ES, Gordon W, Danford TW, Maclsaac KD, Rolfe PA, Conboy CM, Gifford DK y Fraenkel E. 2007. Tissue-specific transcriptional regulation has diverged significantly between human and mouse. Nature 39:730-732.

Parcy F Nilsson O Busch MA Lee I and Weigel D. 1998. A genetic framework for floral patterning. Nature 395:561-566.

Parenicová L, de Folter S, Kieffer M, Horner DS, Favalli C, Busscher J, Ingram RM, Kater MM, Davies B, Angenent GC, Colombo L. 2003. Molecular and phylogenetic analyses of the complete MADS-box transcription factor family in Arabidopsis new openings to the MADS world. Plant Cell 15:1538-1551.

Park SO, Zheng Z, Oppenheimer DG, Hauser BA. 2005. The PRETTY FEW SEEDS2 gene encodes an Arabidopsis homeodomain protein that regulates ovule development. Development 132:841-849.
Pelaz S, Ditta GS, Baumann E, Wisman E, Yanofsky MF. 2000. B and $C$ floral organ identity functions require SEPALLATA MADSbox genes. Nature 405:200-203.

Pelaz S, Tapia-López R, Alvarez-Buylla ER, Yanofsky MF. 2001. Conversion of leaves into petals in Arabidopsis. Curr Biol 11: 182-184.

Peng HZ, Lin EP, Sang QL, Yao S, Jin QY, Hua XQ, Zhu MY. 2007. Molecular cloning, expression analyses and primary evolution studies of REV- and TB1-like genes in bamboo. Tree Physiol 27: 1273-1281.

Peter IS, Davidson EH. 2011. Evolution of gene regulatory networks controlling body plan development. Cell 144:970-985.

Piazza P, Bailey CD, Cartolano M, Krieger J, Cao J, Ossowski S, Schneeberger K, He F, de Meaux J, Hall N, Macleod N, Filatov D, Hay A, Tsiantis M. 2010. Arabidopsis thaliana leaf form evolved via loss of KNOX expression in leaves in association with a selective sweep. Curr Biol 20:2223-2228.

Pigliucci M, Murren CJ, Schlichting CD. 2006. Phenotypic plasticity and evolution by genetic assimilation. J Exp Biol 209: 2362-2367.

Price TD, Qvarnström A, Irwin DE. 2003. The role of phenotypic plasticity driving genetic evolution. Proc Biol Sci 270:1433-1440.

Prunet N, Jack TP. 2014. Flower development in Arabidopsis: there is more than learning your ABCs. In: Riechmann JL, Wellmer F, editors. Flower development - methods and protocols. New York, Springer.

Quatrocchio F, Wing J, van der Woude K, Souer E, de Vetten N, Mol J, Koes R. 1999. Molecular analysis of the anthocyanin2 gene of petunia and its role in the evolution of flower color. Plant Cell 11:1433-1444.

Raff RA. 2000. Evo-devo: the evolution of a new discipline. Nat Rev Genet 1:74-79.

Ramsay L, Comadran J, Druka A, Marshall DF, Thomas WT, Macaulay M, MacKenzie K, Simpson C, Fuller J, Bonar N, Hayes PM, Lundqvist U, Franckowiak JD, Close TJ, Muehlbauer GJ, Waugh R. 2011. INTERMEDIUM-C, a modifier of lateral spikelet fertility in barley, is an ortholog of the maize domestication gene TEOSINTE BRANCHED1. Nat Genet 43:169-172.

Richards EJ. 2008. Population epigenetics. Curr Opin Genet Dev 18:221-226.

Rick CM. 1988. Evolution of mating systems in cultivated plants. In: Gottlieb LD, Jain SK, editors. Plant evolutionary biology. London: Chapman \& Hall.

Riechmann JL, Meyerowitz EM. 1997. MADS domain proteins in plant development. Biol Chem. 378:1079-1101.

Riechmann JL, Heard J, Martin G, Reuber L, Jiang C, Keddie J, Adam L, Pineda O, Ratcliffe OJ, Samaha RR, Creelman R, Pilgrim M, Broun P, Zhang JZ, Ghandehari D, Sherman BK, Yu G. 2000. Arabidopsis transcription factors: genome-wide comparative analysis among eukaryotes. Science 290:2105-2110.

Rieseberg LH, Blackman BK. 2010. Speciation genes in plants. Ann Bot 106:439-455.

Riggs AD, Porter TN. 1996. Overview of epigenetic mechanisms. In: Russo VEA, Martienssen R, Riggs AD, editors. Epigenetic mechanisms of gene regulation. Cold Spring Harbor, NY: Cold Spring Harbor Laboratory Press.

Roeder AHK, Ferrándiz C, Yanofsky MF. 2003. The role of the REPLUMLESS homeodomain protein in patterning the Arabidopsis fruit. Curr Biol 13:1630-1635.

Roeder AHK, Yanofsky MF. 2006. Fruit development in Arabidopsis. Arabidopsis Book 4:e0075.

Roudier F, Ahmed I, Bérard C, Sarazin A, Mary-Huard T, Cortijo S, Bouyer D, Caillieux E, Duvernois-Berthet E, Al-Shikhley L, Giraut $\mathrm{L}$, Després $\mathrm{B}$, Drevensek $\mathrm{S}$, Barneche $\mathrm{F}$, Dèrozier $\mathrm{S}$, Brunaud $\mathrm{V}$, Aubourg S, Schnittger A, Bowler C, Martin-Magniette ML, Robin S, Caboche M, Colot V. 2011. Integrative epigenomic mapping defines four main chromatin states in Arabidopsis. EMBO J 30: 1928-1938.

Saedler H, Becker A, Winter KU, Kirchner C, Theissen G. 2001. MADS-box genes are involved in floral development and evolution. Acta Biochim Pol 48:351-358.

Sandrelli F, Campesan S, Rossetto MG, Benna C, Zieger E, Megighian A, Couchman M, Kyriacou CP, Costa R. 2001. Molecular dissection of the 5' region of no-ontransientA of Drosophila 
melanogaster reveals cis-regulation by adjacent dGpi1 sequences. Genetics 157:765-775.

Sarkar AK, Luijten M, Miyashima S, Lenhard M, Hashimoto T, Nakajima K, Scheres B, Heidstra R, Laux T. 2007. Conserved factors regulate signalling in Arabidopsis thaliana shoot and root stem cell organizers. Nature 446:811-814.

Schlichting CD. 1986. The evolution of phenotypic plasticity in plants. Ann Rev Ecol Syst 17:667-693.

Schlichting CD, Pigliucci M. 1993. Control of phenotypic plasticity by regulatory genes. Am Nat 142:366-370.

Schlichting CD, Pigliucci M. 1995. Gene regulation, quantitative genetics and the evolution of reaction norms. Evol Ecol 9:154168.

Schmidt D, Wilson M, Ballester B, Schwalie PC, Brown GD, Marshall A, Kutter C, Watt S, Martinez-Jimenez CP, Mackay S, Talianidis I, Flicek P, Odom DT. 2010. Five vertebrate ChIP-seq reveals the evolutionary dynamics of transcription factor binding. Science 328:1036-1040.

Sequeira-Mendes J, Aragüez I, Peiró R, Mendez-Giraldez R, Zhang X, Jacobsen SE, Bastolla U, Gutierrez C. 2014. The functiona topography of the arabidopsis genome is organized in a reduced number of linear motifs of chromatin states. Plant Cell 26:23512366.

Shani E, Burko Y, Ben-Yaakov L, Berger Y, Amsellem Z, Goldschmidt A, Sharon E, Ori N. 2009. Stage-specific regulation of Solanum lycopersicon leaf maturation by class 1 KNOTTED1LIKE HOMEOBOX proteins. Plant Cell 21:3078-3092.

Sheldon CC, Rouse DT, Finnegan EJ, Peacock WJ, Dennis ES. 2000. The molecular basis of vernalization: the central role of FLOWERING LOCUS C (FLC). Proc Natl Acad Sci U S A 97 3753-3758.

Sicard A, Thamm A, Marona C, Wha Lee Y, Wahl V, Stinchcombe JR, Wright SI, Kappel C, Lenhard M. 2014. Repeated evolutionary changes of leaf morphology caused by mutations to a homeobox gene. Curr Biol 24:1880-1886.

Simpson CG, Manthri S, Raczynska KD, Kalyna M, Lewandowska D, Kusenda B, Maronova M, Sweykowska-Kulinska Z, Jarmolowski A, Barta A, Brown JW. 2010. Regulation of plant gene expression by alternative splicing. Biochem Soc Trans 38: 667-671.

Smaczniak C, Immink RG, Angenent GC, Kaufmann K. 2012 Developmental and evolutionary diversity of plant MADS-domain factors: insights from recent studies. Development 139:30813098.

Smith H. 1990. Signal perception, differential expression within multigene families and the molecular basis of phenotypic plasticity. Plant Cell Environ 13:585-594.

Sobel JM, Streisfeld MA. 2013. Flower color as a model system for studies of plant evo-devo. Front Plant Sci 4:321.

Soltis DE, Albert VA, Leebens-Mack J, Bell CD, Paterson AH, Zheng C, Sankoff D, Wall K, Soltis PS. 2009. Polyploidy and angiosperm diversification. Am J Bot 96:336-348.

Stam LF, Laurie CC. 1996. Molecular dissection of a major gene effect on a quantitative trait: the level of alcohol dehydrogenase expression in Drosophila melanogaster. Genetics 144:15591564.

Stern DL. 2000. Evolutionary developmental biology and the problem of variation. Evolution 54:1079-1091.

Stern DL and Orgogozo V. 2008. The loci of evolution: how predictable is genetic evolution? Evolution 62:2155-2177.

Stern DL. 2010. Evolution, development, and the predictable genome. Greenwood Village, CO: Roberts \& Co.

Streisfeld MA, Rausher MD. 2009. Genetic changes contributing to the parallel evolution of red floral pigmentation among Ipomoea species. New Phytol 183:751-763.

Studer A, Zhao Q, Ross-Ibarra J, Doebley J. 2011. Identification of a functional transposon insertion in the maize domestication gene tb1. Nat Genet 43:1160-1163.

Takeda T, Suwa $Y$, Suzuki M, Kitano $H$, Ueguchi-Tanaka $M$, Ashikari M, Matsuoka M, Ueguchi C. 2003. The OsTB1 gene negatively regulates lateral branching in rice. Plant $\mathrm{J} 33$ : 513-520.

Tanksley SD, Loaizafigueroa F. 1985. Gametophytic selfincompatibility is controlled by a single major locus on chromo- some 1 in Lycopersicon peruvianum. Proc Natl Acad Sci U S A 82:5093-5096.

Theißen G, Saedler H. 2001. Plant biology: floral quartets. Nature 409:469-471.

Tuch BB, Galgoczy DJ, Hernday AD, Li H, Johnson AD. 2008. The evolution of combinatorial gene regulation in fungi. PLoS Biol 6: e38.

Turck F, Coupland G. 2014. Natural variation in epigenetic gene regulation and its effects on plant developmental traits. Evolution 68:620-631.

Urbanus SL, Martinelli AP, Dinh QDP, Aizza LCB, Dornelas MC, Angenent GC, Immink RGH. 2010. Intercellular transport of epidermis-expressed MADS domain transcription factors and their effect on plant morphology and floral transition. Plant $\mathrm{J}$ 63: 60-72.

Vaughn MW, Tanurdzić M, Lippman Z, Jiang H, Carrasquillo R, Rabinowicz PD, Dedhia N, McCombie WR, Agier N, Bulski A, Colot V, Doerge RW, Martienssen RA. 2007. Epigenetic natural variation in Arabidopsis thaliana. PLoS Biol 5:e174.

Verdonk JC, Haring MA, van Tunen AJ, Schuurink RC. 2005. ODORANT1 regulates fragrance biosynthesis in Petunia flowers. Plant Cell 17:1612-1624.

Vergara-Silva F, Espinosa-Matías S, Ambrose BA, VázquezSantana S, Martínez-Mena A, Márquez-Guzmán J, Martínez E, Meyerowitz EM, Álvarez-Buylla ER. 2003. Inside-out flowers characteristic of Lacandonia schismatica evolved at least before its divergence from a closely related taxon, Triuris brevistylis. Int J Plant Sci 164:345-357.

Vlad D, Kierzkowski D, Rast MI, Vuolo F, Delle loio R, Galinha C, Gan X, Hajheidari M, Hay A, Smith RS, Huijser P, Bailey CD, Tsiantis M. 2014. Leaf shape evolution through duplication, regulatory diversification, and loss of a homeobox gene. Science 343:780-783.

Wagner GP, Lynch VJ. 2008. The gene regulatory logic of transcription factor evolution. Trends Ecol Evol 23:377-385.

Wallace B. 1963. Genetic diversity, genetic uniformity, and heterosis. Can J Genet Cytol 5:239-253.

Walker AR, Lee E, Bogs J, McDavid DAJ, Thomas MR, Robinson S. 2007. White grapes arose through the mutation of two similar adjacent regulatory genes. Plant J 49:772-785.

Wang RL, Stec A, Hey J, Lukens L, Doebley J. 1999. The limits of selection during maize domestication. Nature 398:236239.

Wang YQ, Melzer R, Theissen G. 2011. A double-flowered variety of lesser periwinkle (Vinca minor fl. pl.) that has persisted in the wild for more than 160 years. Ann Bot 107:1445-1452.

Weigel D, Meyerowitz EM. 1993. Activation of floral homeotic genes in Arabidopsis. Science 261:1723-1726.

West-Eberhard MJ. 2003. Developmental plasticity and evolution. New York: Oxford University Press, Inc.

White KP, Rifkin SA, Hurban P, Hogness DS. 1999. Microarray analysis of Drosophila development during metamorphosis. Science 286:2179-2184.

Whitman DW, Agrawal AA. 2009. What is phenotypic plasticity and why is it important? In: Whitman DW, Ananthrakrishnan TN, editors. Phenotypic plasticity in insects: mechanisms and consequences. New York: CRC Press.

Wilkins AS. 2002. The evolution of developmental pathways. Sunderland, MA: Sinauer Associates Inc.

Williams TM, Selegue JE, Werner T, Gompel N, Kopp A, Carroll SB. 2008. The regulation and evolution of a genetic switch controlling sexually dimorphic traits in Drosophila. Cell 134:610-623.

Willmore KE. 2012. An introduction to evolutionary developmental biology. Evo Edu Outreach 5:181-183.

Wilson MD, Barbosa-Morais NL, Schmidt D, Conboy CM, Vanes L, Tybulewicz VLJ, Fisher EMC, Tavaré S, Odom DT. 2008. Species-specific transcription in mice carrying human chromosome 21. Science 322:434-438.

Wittkopp PJ, Haerum BK, Clark AG. 2004. Evolutionary changes in cis and trans gene regulation. Nature 430:85-88.

Wittkopp PJ, Kalay G. 2012. Cis-regulatory elements: molecular mechanisms and evolutionary processes underlying divergence. Nat Rev Genet 13:59-69. 
Wray GA, Hahn MW, Abouheif E, Balhoff JP, Pizer M, Rockman MV, Romano LA. 2003. The evolution of transcriptional regulation in eukaryotes. Mol Biol Evol 20:1377-1419.

Wray GA. 2007. The evolutionary significance of cis-regulatory mutations. Nat Rev Genet 8:206-216.

Wray GA. 2013. Genomics and the evolution of phenotypic traits. Annu Rev Ecol Evo Syst 44:51-72.

Xiong Y, Liu T, Tian C, Sun S, Li J, Chen M. 2005. Transcription factors in rice: a genome-wide comparative analysis between monocots and eudicots. Plant Mol Biol 59:191-203.

Yamaguchi T, Nukazuka A, Tsukaya H. 2012. Leaf adaxial-abaxial polarity specification and lamina outgrowth: evolution and development. Plant Cell Physiol 53:1180-1194.

Yang Y, Fanning L, Jack T. 2003. The K domain mediates heterodimerization of the Arabidopsis floral organ identity proteins, APETALA3 and PISTILLATA. Plant J 33:47-59.

Yang Y, Jack T. 2004. Defining subdomains of the $\mathrm{K}$ domain important for protein-protein interactions of plant MADS proteins. Plant Mol Biol 55:45-59.
Yuan YW, Sagawa JM, Young RC, Christensen BJ, Bradshaw HD Jr. 2013. Genetic dissection of a major anthocyanin QTL contributing to pollinator-mediated reproductive isolation between sister species of Mimulus. Genetics 194:255-263.

Zhang W, Lee HR, Koo DH, Jiang J. 2008. Epigenetic modification of centromeric chromatin: hypomethylation of DNA sequences in the CENH3-associated chromatin in Arabidopsis thaliana and maize. Plant Cell 20:25-34.

Zheng W, Zhao H, Mancera E, Steinmetz LM, Snyder M. 2010. Genetic analysis of variation in transcription factor binding in yeast. Nature 464:1187-1191.

Zuckerkandl E. 1968. Hemoglobins, Haeckel's "biogenic law", and molecular aspects of development. In: Rich A, Davidson N, editors. Structural chemistry and molecular biology. San Francisco, CA: WH Freeman.

Zufall RA, Rausher MD. 2004. Genetic changes associated with floral adaptation restrict future evolutionary potential. Nature 428:847-850. 